\title{
Photochemical organonitrate formation in wet aerosols
}

\author{
Yong Bin Lim ${ }^{1,2}$, Hwajin Kim ${ }^{1,3}$, Jin Young Kim ${ }^{1,3}$, and Barbara J. Turpin ${ }^{4}$ \\ ${ }^{1}$ Center for Environment, Health and Welfare Research, Korea Institute of Science and Technology, Seoul 02792, \\ Republic of Korea \\ ${ }^{2}$ Department of Environmental Sciences, Rutgers University, New Brunswick, New Jersey 08901, USA \\ ${ }^{3}$ Department of Energy and Environmental Engineering, University of Science and Technology, Daejeon 34113, \\ Republic of Korea \\ ${ }^{4}$ Department of Environmental Science and Engineering, University of North Carolina, Chapel Hill, \\ North Carolina 27599, USA
}

Correspondence to: Yong Bin Lim (ylim@kist.re.kr), Jin Young Kim (jykim@kist.re.kr)

Received: 22 April 2016 - Published in Atmos. Chem. Phys. Discuss.: 3 May 2016

Revised: 7 September 2016 - Accepted: 22 September 2016 - Published: 11 October 2016

\begin{abstract}
Water is the most abundant component of atmospheric fine aerosol. However, despite rapid progress, multiphase chemistry involving wet aerosols is still poorly understood. In this work, we report results from smog chamber photooxidation of glyoxal- and $\mathrm{OH}-$ containing ammonium sulfate or sulfuric acid particles in the presence of $\mathrm{NO}_{x}$ and $\mathrm{O}_{3}$ at high and low relative humidity. Particles were analyzed using ultra-performance liquid chromatography coupled to quadrupole time-of-flight mass spectrometry (UPLCQ-TOF-MS).

During the $3 \mathrm{~h}$ irradiation, $\mathrm{OH}$ oxidation products of glyoxal that are also produced in dilute aqueous solutions (e.g., oxalic acids and tartaric acids) were formed in both ammonium sulfate (AS) aerosols and sulfuric acid (SA) aerosols. However, the major products were organonitrogens (CHNO), organosulfates (CHOS), and organonitrogen sulfates (CHNOS). These were also the dominant products formed in the dark chamber, indicating non-radical formation. In the humid chamber ( $>70 \%$ relative humidity, $\mathrm{RH})$, two main products for both AS and SA aerosols were organonitrates, which appeared at $m / z^{-} 147$ and 226. They were formed in the aqueous phase via non-radical reactions of glyoxal and nitric acid, and their formation was enhanced by photochemistry because of the photochemical formation of nitric acid via reactions of peroxy radicals, $\mathrm{NO}_{x}$ and $\mathrm{OH}$ during the irradiation.
\end{abstract}

\section{Introduction}

Atmospheric aerosols affect human health and climate (Seinfeld and Pandis, 1998), and a large fraction is secondary organic aerosol (SOA) (Zhang et al., 2007). SOA forms via partitioning of semivolatile organic products from gas-phase oxidation of volatile organic compounds (VOCs) (Odum et al., 1996; Pankow, 1994), multiphase reactions involving aerosols (Jang et al., 2002; Kalberer et al., 2004), and aqueous-phase reactions in cloud/fog waters (Blando and Turpin, 2000). SOA formation via aqueous chemistry $\left(\mathrm{SOA}_{\mathrm{aq}}\right)$ has been suggested by recent laboratory, field, and modeling studies (El-Sayed et al., 2015; Ervens et al., 2011; Gilardoni et al., 2016; Gong et al., 2011; Lee et al., 2011, 2012; Lin et al., 2012; Liu et al., 2012a, b; McNeill et al., 2012; Myriokefalitakis et al., 2011; Ortiz-Montalvo et al., 2012, 2014; Tan et al., 2012; Zhou et al., 2011). Including $\mathrm{SOA}_{\mathrm{aq}}$ is likely to improve model predictions, which currently underestimate the ambient concentration and oxidation state of organic aerosols. Water-soluble organic compounds with a small carbon number $(\mathrm{C} 2-\mathrm{C} 3)$ are not considered by the partitioning theory (Pankow, 1994) because of their high vapor pressure. However, they are potential $\mathrm{SOA}_{\mathrm{aq}}$ precursors. In addition, these water-soluble organics and liquid water are abundant in the atmosphere (Blando and Turpin, 2000; Carlton and Turpin, 2013; Liao and Seinfeld, 2005).

$\mathrm{SOA}_{\mathrm{aq}}$ formation is expected in cloud/fog droplets and aerosol waters via radical and non-radical reactions (Lim 
et al., 2010; McNeill et al., 2012). Since OH radicals with the concentrations of $10^{-14}-10^{-12} \mathrm{M}$ are available in the atmospheric aqueous phase (Arakaki et al., 2013; Ervens et al., 2014), water-soluble organic compounds (e.g., glyoxal, methylglyoxal) undergo photooxidation, forming dicarboxylic acids (e.g., oxalic acids) via peroxy radical reactions and oligomers via organic radical-radical reactions (Altieri et al., 2008; Lim et al., 2010, 2013; Tan et al., 2009, 2012). Even without $\mathrm{OH}$ radicals, the photolysis of pyruvic acid also forms oligomers in concentrated solutions (Guzman et al., 2006). Organic compounds form organosulfates with sulfuric acids via acid catalysis (i.e., with acidic sulfate) (Surratt et al., 2007a, 2008, 2010). Water-soluble organic compounds like glyoxal and methylglyoxal hydrate and form oligomers through hemiacetal formation and aldol condensation, especially in evaporating droplets (Corrigan et al., 2008; Liggio et al., 2005; Loeffler et al., 2006; Noziere et al., 2009; Schwier et al., 2010). Ammonium ions, which are abundant in atmospheric aerosols (Zhang et al., 2007), form nitrogencontaining organics including imidazoles with water-soluble organic compounds (Galloway et al., 2009; Kampf et al., 2012; Noziere and Cordova, 2008; Sareen et al., 2010; Yu et al., 2011), and also act as catalysts enhancing oligomer formation (Nguyen et al., 2014; Noziere et al., 2009). Watersoluble carboxylic acids (Blando and Turpin, 2000; Chebbi and Carlier, 1996) and cations (e.g., $\mathrm{Na}^{+}, \mathrm{K}^{+}, \mathrm{NH}_{4}^{+}$, protonated amines) form low-volatility carboxylate salts (Drozd et al., 2014; Ortiz-Montalvo et al., 2014; Paciga et al., 2014; Smith et al., 2010).

Although these findings have significantly improved our understanding of aqueous chemistry, atmospheric processes like gas-wet particle partitioning of water-soluble organic compounds, $\mathrm{OH}$ radicals, and water in aerosols are still poorly understood. Therefore, organic chemistry in the presence of wet aerosol warrants further study. Studies of wet aerosol chemistry to date have demonstrated that the chemistry in wet aerosols can be quite different than that under dilute (cloud-relevant) conditions. For example, in reaction vessel experiments for photooxidation of glyoxal or methylglyoxal in the dilute aqueous phase, sulfuric acid does not affect the formation of major products (e.g., oxalic acid) (Tan et al., 2009), while both smog chamber and field studies observe organosulfate formation in aerosols in the presence of sulfuric acid, which contributes both liquid water and acidity to condensed-phase aerosol chemistry (Galloway et al., 2009; Surratt et al., 2007a, b; Tolocka and Turpin, 2012). In fact, several key questions remain to be answered. For example, the major sink of nitrate radicals in the aqueous phase is the formation of $\mathrm{HNO}_{3}$ (Kirkland et al., 2013). However, it should be noted that organonitrates are commonly observed in rainwater (Altieri et al., 2009), clouds (Boone et al., 2015), and wet aerosols (Hodas et al., 2014). Are organonitrates formed in the aqueous phase? Are they taken up into atmospheric waters after gas-phase formation during the daytime $\left(\mathrm{ROO} \cdot+\mathrm{NO} \rightarrow \mathrm{RONO}_{2}\right)$ or the nighttime $\left(\mathrm{R}+\mathrm{NO}_{3} \rightarrow\right.$
$\mathrm{RONO}_{2}$ )? Alternatively, are they formed via aqueous chemistry?

A smog chamber is ideal to explore condensed-phase chemistry to address these issues. Volkamer et al. (2009) conducted smog chamber experiments for aqueous chemistry of glyoxal in wet particles. In their experiments, glyoxal was photochemically produced from the acetylene-OH reaction in the gas phase, and partitioned into wet seed particles (e.g., ammonium sulfate, ammonium bisulfate, fulvic acid) with the relative humidity $(\mathrm{RH})$ range from $\sim 20$ to $\sim 60 \%$. Clearly, glyoxal is volatile, not semivolatile. Nevertheless, it forms SOA due to the high water solubility. This provided evidence that SOA yields were correlated with the water content, not the organic mass portion in aerosols. Then, Galloway et al. (2009) studied glyoxal uptake by ammonium sulfate particles in a smog chamber, conducting dark and irradiated experiments at $\sim 60-70 \% \mathrm{RH}$. While Volkamer et al. (2009) focused on SOA yields, Galloway et al. (2009) characterized aerosol products from dark/irradiated reactions using a high-resolution time-of-flight aerosol mass spectrometer, identifying imidazoles among other organic nitrogen products from dark reactions and glycolic acid sulfates $\left(\mathrm{C}_{2} \mathrm{H}_{3} \mathrm{O}_{6} \mathrm{~S}_{1}\right)$ among other organosulfate products from irradiated reactions (note that Volkamer et al., 2009, conducted OH radical chemistry, but Galloway et al., 2009, had no $\mathrm{OH}$ source). Note that glyoxal is used as a surrogate of water-soluble organic compounds in ambient wet aerosols, to explore non-radical and radical reactions in the condensed phase leading to SOA. Later, Kampf et al. (2012) studied further glyoxal-ammonium sulfate aerosols, identifying various imidazoles and oligomers under dark reactions using a high performance liquid chromatograph coupled with a tandem mass spectrometer. Chamber studies for isoprene epoxides (IEPOX) in the aqueous phase have also been conducted. Surratt et al. (2010) observed in a dark chamber $(\sim 30 \%$ RH) IEPOX taken up by acidic sulfate aerosols that formed oligomers presumably in the aqueous phase, since sulfuric acid takes up water even at low RH. Nguyen et al. (2014) observed that liquid water content strongly correlated with IEPOX uptake and oligomer formation by ammonium sulfate seed particles in the presence of aerosol liquid water.

There are still few smog chamber studies addressing condensed-phase chemistry explicitly in terms of radical reactions (irradiated reactions) and non-radical reactions (dark reactions); these two types of aqueous chemistry must be explored to understand $\mathrm{SOA}_{\mathrm{aq}}$ formation in aerosols. One of the challenges in studies of SOA formation through wet aerosol chemistry is that the concentration of aerosol water, the medium of the aqueous-phase reactions, depends on (1) the hygroscopicity of aerosols, (2) the concentration of aerosol particles and (3) RH. Furthermore, product formation also depends on (1) the gas-phase transport of water-soluble organic compounds, (2) OH partitioning between the gas and 
aqueous phases, and (3) competition in the aqueous phase between photooxidation and dark (non-radical) reactions.

In this work, we conduct multiphase photochemical oxidation and dark reactions in the presence of wet aerosols: glyoxal- $\mathrm{H}_{2} \mathrm{O}_{2}$-ammonium sulfate aerosols (AS aerosols) and glyoxal- $\mathrm{H}_{2} \mathrm{O}_{2}$-sulfuric acid aerosols (SA aerosols) in a smog chamber under low $(<5 \% \mathrm{RH})$ and high $(>70 \% \mathrm{RH})$ humidity conditions. Ammonium sulfate and sulfuric acid were used for seed particles to observe ammonium interactions, liquid water, and acidity effects. $\mathrm{H}_{2} \mathrm{O}_{2}$ provided a source of $\mathrm{OH}$ radicals in the wet aerosols during the irradiation. $\mathrm{NO}_{x}$ and $\mathrm{O}_{3}$ were initially introduced into the chamber with modest concentrations $\left(\left[\mathrm{NO}_{x}\right]_{\text {initial }}=\right.$ $3-83 \mathrm{ppb},\left[\mathrm{O}_{3}\right]_{\text {initial }}=0-12 \mathrm{ppb}$ ) to reflect chemistry under anthropogenic influences (Carlton and Turpin, 2013; Ervens et al., 2011). After chamber reactions wet aerosols were characterized by ultra-performance liquid chromatography quadrupole time-of-flight mass spectrometry (UPLCQ-TOF-MS).

\section{Experimental section}

\subsection{Chemicals}

The following chemicals were used in this study: glyoxal solution (Sigma-Aldrich) $40 \%$ in $\mathrm{H}_{2} \mathrm{O}$ (by weight), hydrogen peroxide (Kanto Chemical Co. Inc.) $30 \%$ in $\mathrm{H}_{2} \mathrm{O}$ (by weight), ammonium sulfate (Sigma-Aldrich) $99.999 \%$ (by weight), sulfuric acid (Junsei Chemical Co. Inc.) $95.0 \%$ in $\mathrm{H}_{2} \mathrm{O}$ (by volume), and nitric acid (Sigma Aldrich) $70 \%$ in $\mathrm{H}_{2} \mathrm{O}$ (by weight).

\subsection{Environmental chamber method}

Photooxidation/dark experiments for AS aerosols and SA aerosols were conducted in a $5 \mathrm{~m}^{3}$ PTFE environmental chamber at the Korea Institute Science and Technology (KIST), Seoul, Republic of Korea. The chamber was initially filled with clean/dry air $(<0.5 \mathrm{ppb}$ NMHC, $<5 \% \mathrm{RH})$ at $20-25^{\circ} \mathrm{C}$ and atmospheric pressure. AS aerosols were made by atomizing the aqueous solution of $1 \mathrm{mM}$ glyoxal, $200 \mu \mathrm{M} \mathrm{H} \mathrm{H}_{2} \mathrm{O}_{2}$, and $0.012 \mathrm{M}\left(\mathrm{NH}_{4}\right)_{2} \mathrm{SO}_{4}$, and SA aerosols were made by atomizing the aqueous solution of $1 \mathrm{mM}$ glyoxal, $200 \mu \mathrm{M} \mathrm{H}_{2} \mathrm{O}_{2}$, and $0.012 \mathrm{M} \mathrm{H}_{2} \mathrm{SO}_{4}$. Note that atomized particles were passed through a diffusion dryer (3062$\mathrm{NC}$, TSI; residence time $\sim 5 \mathrm{~s}$ ) before introducing them to the chamber to minimize the water content. $200 \mu \mathrm{M} \mathrm{H}_{2} \mathrm{O}_{2}$, previously used by Nguyen et al. (2013) in flow tube studies, was used here since this concentration generates $\sim 10^{-14}$ $\mathrm{M}$, an atmospheric aqueous $\mathrm{OH}$ concentration (Arakaki et al., 2013), during the reaction with $1 \mathrm{mM}$ glyoxal, according to the updated full kinetic model (Lim et al., 2010, 2013; Lim and Turpin, 2015) (Fig. S1 in the Supplement; model details are in Sect. 3.3). The smog chamber background levels were $<40$ particles and $\sim 10^{-2} \mu \mathrm{g} \mathrm{m} \mathrm{m}^{3}$. Atomized aerosols with mass concentrations of $70-180 \mu \mathrm{g} \mathrm{m}^{3}$ and a size of 70 $90 \mathrm{~nm}$ (geometric mean diameter) were then introduced into the chamber for photooxidation or dark reactions. Concentrations of $\mathrm{NO}_{x}, \mathrm{O}_{3}$, and particle mass in the smog chamber can be related to a moderate haze condition in urban areas, particularly observed in Seoul or Beijing.

The photooxidation was initiated by turning on blacklights, which generate tropospheric ultraviolet (UV) light $(340-400 \mathrm{~nm})$ with a peak intensity at $359 \mathrm{~nm}$. For humid condition experiments, the KIST humidifier was used to achieve up to $\sim 90 \% \mathrm{RH}$. RH and temperature were measured using a Kimo AMI 300 multifunction meter. This humidifier was developed by modifying an existing commercial humidifier. Water spray and evaporation pan were specially designed to generate water steam rapidly. While adding water vapors into the chamber, we monitored scanning mobility particle sizer (SMPS) to ensure no water droplet was introduced. All experiments were conducted in moderate $\mathrm{O}_{3}$ and $\mathrm{NO}_{x}$ conditions $\left(\left[\mathrm{O}_{3}\right]_{\text {initial }}=0-13 \mathrm{ppb}\right.$, $[\mathrm{NO}]_{\text {initial }}=2-81 \mathrm{ppb}$ and $\left.\left[\mathrm{NO}_{2}\right]_{\text {initial }}=0-5 \mathrm{ppb}\right)$. NO and $\mathrm{NO}_{x}$ concentrations were measured using an $\mathrm{NO}-\mathrm{NO}_{2}-\mathrm{NO}_{x}$ Analyzer (Thermo Scientific Model 42i). Ozone concentrations were measured using an Ozone Analyzer (Thermo Scientific Model 49i). We conducted 14 experiments in an irradiated/dark chamber, adjusting relative humidity from 5 to $90 \%$. Table S1 in the Supplement summarizes experimental conditions. Fractions of aerosol liquid water (ALW) in aerosols were estimated using the extended aerosol inorganic model (E-AIM) (Wexler and Clegg, 2002), and are also included in the table. For the ALW estimations, Model II $\mathrm{CH}^{+}$, $\mathrm{NH}_{4}^{+}, \mathrm{SO}_{4}^{2-}, \mathrm{NO}_{3}^{-}, \mathrm{H}_{2} \mathrm{O}$, and organic compounds) was used, and neither radical nor non-radical reactions in the condensed phase were considered.

\subsection{Filter extraction and aerosol analysis}

At chamber reaction times of $0,30,60,120$, and $180 \mathrm{~min}$, aerosols were collected on blank Teflon filters $(25 \mathrm{~mm}$, $1.0 \mu \mathrm{m}$, Pall Corporation) for $10 \mathrm{~min}$ at a sampling rate of 10 LPM. (Only 0 and $180 \mathrm{~min}$ samples were collected for dark reactions.) These filter samples were extracted with $5 \mathrm{~mL}$ Milipore water $(18.2 \mathrm{M} \Omega$ ) for $20 \mathrm{~min}$ sonication. Note that any possible hydrogen peroxide formed during sonication is not likely to affect aqueous-phase photooxidation. According to our previous reaction vessel experiments (Tan et al., 2009), hydrogen peroxide does not react with glyoxal or oxalic acid. It only oxidizes glyoxylic acid; but in these smog chamber experiments, glyoxylic acid evaporates. Ultraperformance liquid chromatography coupled to quadrupole time-of-flight mass spectrometry (UPLC-Q-TOF-MS) (Waters, Synapt G2) was used to examine the elemental composition of aerosol samples. The capillary voltage and the capillary temperature were $-2500 \mathrm{~V}$ and $350^{\circ} \mathrm{C}$, respectively for negative mode analyses. Positive-mode analyses were conducted with a capillary voltage of $2500 \mathrm{~V}$ and a 
capillary temperature of $250^{\circ} \mathrm{C}$. The aerosol samples were diluted with methanol twofold in volume (i.e., 50:50 water/methanol), then were immediately introduced into the electrospray ionization source by direct infusion, with a flow rate of $2.54 \mathrm{~mL} \mathrm{~h}^{-1}$. Since no column was used for separation, clusters could be formed during the ionization.

Two standard solutions, AS solution (1 mM glyoxal, $200 \mu \mathrm{M} \mathrm{H} \mathrm{O}_{2}$, and $\left.0.012 \mathrm{M}\left(\mathrm{NH}_{4}\right)_{2} \mathrm{SO}_{4}\right)$ and $\mathrm{SA}$ solution (1 mM glyoxal, $200 \mu \mathrm{M} \mathrm{H} \mathrm{O}_{2}$, and $0.012 \mathrm{M} \mathrm{H}_{2} \mathrm{SO}_{4}$ ), were also analyzed by UPLC-Q-TOF-MS using the method described above.

Organic compounds (CHO), organonitrogens (CHNO), organosulfates (CHOS), and organonitrogen sulfates (CHNOS) were analyzed both in the negative and positive modes. In the negative mode, undissociated acid compounds (i.e., $[\mathrm{M}-\mathrm{H}]^{-}$), such as carboxylic acids, organonitrates, and organosulfates, are detected. In addition, some organonitrates are detected as $\mathrm{Cl}^{-}$adducts. In the positive mode, glyoxal, glyoxal oligomers, and reduced organonitrogen compounds (e.g., imines; note that imidazoles are imines) are detected via protonation $\left([\mathrm{M}+\mathrm{H}]^{+}\right)$or as sodium adducts $\left([\mathrm{M}+\mathrm{Na}]^{+}\right)$. Elemental formulas were assigned by MIDAS Formula Calculator (version 1.2.3) within the uncertainty of $150 \mathrm{ppm}$ based on the mass accuracy of measured nitrate peaks $\left(\mathrm{m} / \mathrm{z}^{-} 62\right)$. Note that unlike Fourier transform ion cyclotron mass spectrometry (FTICR-MS), whose uncertainty is below $1 \mathrm{ppm}$, it is well known that uncertainties of TOF could be high (Smith et al., 2013). In addition to this, the elemental formulas for organosulfates (with 32S) were confirmed by the coexistence of the formula identical with the sulfur isotope $(34 \mathrm{~S})$, present with a signal intensity reduced to $\sim 100$ times smaller in a mass spectrum. (Note that natural abundance is $95 \% 32 \mathrm{~S}$ and $4 \% 34 \mathrm{~S}$.) Similarly, $\mathrm{Cl}^{-}$adducts $(35 \mathrm{Cl})$ were confirmed by chlorine isotope $(37 \mathrm{Cl})$ adducts, with an intensity reduced by $\sim 20$ times. (Note that natural abundance is $75 \% 35 \mathrm{Cl}$ and $25 \%$ 37Cl.)

\subsection{MS/MS analysis for $m / z^{-147}$ and standard MS analysis for $m / z^{-} 147$ and 226}

The smog chamber product peak at $\mathrm{m} / \mathrm{z}^{-} 147$ was further analyzed by a liquid chromatograph tandem mass spectrometer (LC-MS/MS; 6460 Agilent Triple Quadrupole). Again, the mobile phase was 50:50 water/methanol, and the direct injection with a flow rate of $0.1 \mathrm{~mL} \mathrm{~min}^{-1}$ (no column) was used. The sample was analyzed in the negative mode. The capillary voltage and the capillary temperature were $-3000 \mathrm{~V}$ and $350^{\circ} \mathrm{C}$, respectively. A standard solution prepared by mixing glyoxal $(7.6 \mathrm{mM})$ and nitric acid $(15 \mathrm{mM})$ was analyzed by UPLC-Q-TOF-MS using the method described above.

\section{Results and discussion}

\subsection{Photochemical organonitrate formation in wet aerosols}

During the irradiation for both AS and SA aerosols in the humid chamber $(>70 \% \mathrm{RH})$, the major products, organonitrates $\left(m / z^{-} 147\right.$ and 226), were likely formed by nonradical reactions of glyoxal with nitric acid in the aqueous phase of wet aerosols (Fig. 1a and b), and nitric acid $\left(\mathrm{m} / \mathrm{z}^{-}\right.$62) is formed via radical reactions in the gas-phase system of glyoxal-NO $\mathrm{NO}_{x}-\mathrm{OH}$. LC-MS/MS analysis was conducted for $m / z^{-} 147$, and fragments were $m / z^{-} 62$ and 103 (Fig. S2 in the Supplement). $m / z^{-} 62$ indicates nitric acid, and $m / z^{-} 103$ is a loss of $44\left(\mathrm{CO}_{2}\right)$, suggesting that the parent molecule is a carboxylic acid. The standard solution of the glyoxal- $\mathrm{HNO}_{3}$ mixture analyzed by UPLC-Q-TOF-MS showed the major peaks at $m / z^{-} 62,147$, and 226 (Fig. S3 in the Supplement). This confirms that $m / z^{-} 147$ and 226 can be formed via aqueous non-radical reactions of glyoxal and nitric acid without UV. According to the MIDAS molecular calculator, these two peaks are organonitrates $\left(m / z^{-} 147\right.$, $\left.\mathrm{C}_{6} \mathrm{H}_{2} \mathrm{~N}_{2} \mathrm{O}_{12}(z=2) ; m / z^{-} 226, \mathrm{C}_{4} \mathrm{H}_{1} \mathrm{~N}_{1} \mathrm{O}_{8} \mathrm{C}_{l 1}\right)$, and not likely nitric acid adducts to glyoxal (clusters). The proposed formation and molecular structures are illustrated in Scheme 4. Other organonitrates may form through this mechanism as well. However, the chemical formula provided herein has the smallest error compared to the measured mass. It appears that nitric acid undergoes nitrate ester formation $\left(\mathrm{R}-\mathrm{OH}+\mathrm{HNO}_{3} \mathrm{R}-\mathrm{ONO}_{2}+\mathrm{H}_{2} \mathrm{O}\right)($ Boschan et al., 1955) and oxidizes some hydroxyl groups (Connelly et al., 2012). Therefore, $m / z^{-} 147$ and 226 are organonitrates formed by the aqueous-phase reaction of glyoxal and nitric acid. $m / z^{-} 147$ is likely to be doubly charged $(z=2)$, and this is supported by the coexistence of $m / z^{-} 147.5(\Delta z=0.5)$. On the other hand, $m / z^{-} 226$ is likely to be a $\mathrm{Cl}^{-}$adduct organonitrate. $\mathrm{Cl}^{-}$adducts for organonitrates have been observed (Bouma and Jennings, 1981; Lawrence et al., 2001; Rajapakse et al., 2016; Zhu and Cole, 2000), and MIDAS does not propose realistic organonitrates without $\mathrm{Cl}^{-}$. The uncertainty for the mass of $\mathrm{Cl}$ adducts is reasonably low ( $\sim 50 \mathrm{ppm}$ ). $\mathrm{Cl}^{-}$adducts are confirmed by the coexistence of $m / z^{-} 228(\Delta z=2)$, organonitrates adducted by $\mathrm{Cl}^{-}$isotope $(37 \mathrm{Cl})$ with the low mass uncertainty (10-30 ppm).

Despite the non-radical formation of organonitrates, nitric acid was photochemically formed during the irradiation (Scheme 1a). It is also possible that nitric acid is formed in the dark (Scheme 1b). Indeed, $m / z^{-}$62, 147, and 226 initially appeared for AS and SA aerosols in dark reactions (Fig. 2e and f). However, these peaks disappeared in $3 \mathrm{~h}$ (Fig. S4 in the Supplement). This suggests that photochemical formation of nitric acid is continuous during the irradiation. The chamber was initially filled with $\mathrm{NO}$ and little $\mathrm{NO}_{2}$, but $\mathrm{NO}$ was converted to $\mathrm{NO}_{2}$ as irradiation proceeded. Peroxy radicals are effective for the $\mathrm{NO}-\mathrm{NO}_{2}$ con- 
(a)

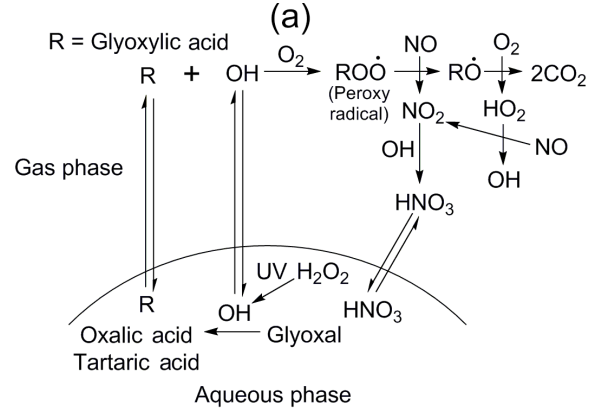

(b)

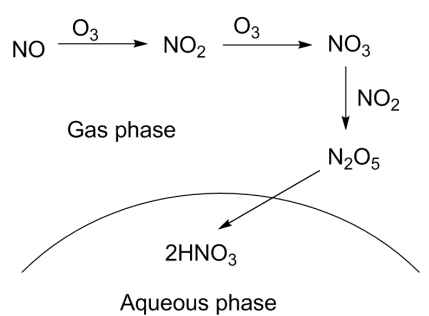

Scheme 1. Nitric acid formation in the UV (a) and in the dark (b).

(a)

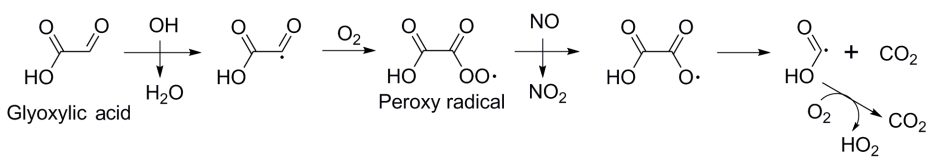

(b)

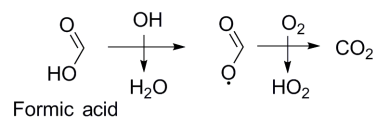

(c)

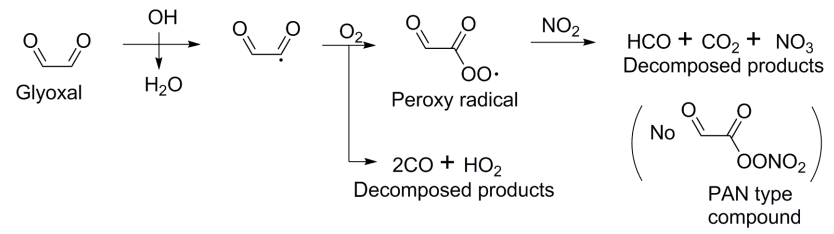

Scheme 2. Mechanisms of gas-phase $\mathrm{OH}$ reactions in the presence of $\mathrm{NO}_{x}$ for glyoxylic acid (a), formic acid (b), and glyoxal (c).

version (Atkinson and Arey, 2003), and our measured $\mathrm{NO}_{x}$ levels support this. During the irradiation of AS aerosols (experiment no. 1, Table S1 in the Supplement), the concentration of $\mathrm{NO}_{2}$ increased from 4.0 to $20.0 \mathrm{ppb}\left(\Delta\left[\mathrm{NO}_{2}\right]\right.$ $=16.0 \mathrm{ppb}$ ), while the concentration of $\mathrm{NO}$ was reduced from 24.0 to $5.5 \mathrm{ppb}(\Delta[\mathrm{NO}]=-18.5 \mathrm{ppb})$. Another photochemical experiment for AS aerosols (experiment no. 2) also shows a significant increase of $\left[\mathrm{NO}_{2}\right]\left(\Delta\left[\mathrm{NO}_{2}\right]=10.0 \mathrm{ppb}\right.$, $\Delta[\mathrm{NO}]=-3.8 \mathrm{ppb})$. However, in the photochemical experiment for AS aerosols containing no glyoxal (experiment no. 7), $\mathrm{NO}_{2}$ only increased by $0.7 \mathrm{ppb}$, while the initial [NO] was similar to Experiment no. 2. Notice that $\mathrm{O}_{3}$ increased. This is due to photolysis of $\mathrm{NO}_{2}$.

Photochemistry on wet aerosols may lead to volatile organic products that contribute to gas-phase peroxy radicals. Glyoxal is not likely to evaporate due to high water solubility (effective $\mathrm{H}_{\text {glyoxal }} \sim 2 \mathrm{e} 7$ ) (Ervens and Volkamer, 2010). Among products of glyoxal-OH reactions, glyoxylic acid and formic acid are not very water-soluble $\quad\left(\mathrm{H}_{\text {glyoxylic acid }}=9.12 \times 10^{3} \mathrm{M} \mathrm{atm}^{-1}\right.$; $\mathrm{H}_{\text {formic acid }}=5.50 \times 10^{3}$ ), so they could evaporate to the gas phase and undergo $\mathrm{OH}$ radical reactions, forming peroxy radicals. (Model simulations are discussed in Sect. 3.3.) OH radicals produced via photolysis of $\mathrm{H}_{2} \mathrm{O}_{2}$ could evaporate while reacting with glyoxal in the aqueous phase $\left(\mathrm{H}_{\mathrm{OH}}=30 \mathrm{M} \mathrm{atm}^{-1}\right)$. Scheme 2 shows gas-phase $\mathrm{OH}$ reactions of glyoxylic acid and formic acid. In the gas phase, glyoxylic acid $(\mathrm{HO}(\mathrm{O}) \mathrm{CC}(\mathrm{O}) \mathrm{H})$ reacts with $\mathrm{OH}$ and $\mathrm{O}_{2}$, forming peroxy radicals $(\mathrm{HO}(\mathrm{O}) \mathrm{CC}(\mathrm{O}) \mathrm{OO} \cdot)$, which convert $\mathrm{NO}$ to $\mathrm{NO}_{2}$ $\left(\mathrm{HO}(\mathrm{O}) \mathrm{CC}(\mathrm{O}) \mathrm{OO} \cdot+\mathrm{NO} \rightarrow \mathrm{HO}(\mathrm{O}) \mathrm{CC}(\mathrm{O}) \mathrm{O} \cdot+\mathrm{NO}_{2}\right)$.

Although there is no literature available for $\mathrm{OH}$ reactions of glyoxylic acid in the gas phase, these peroxy radicals $(\mathrm{HO}(\mathrm{O}) \mathrm{CC}(\mathrm{O}) \mathrm{OO} \cdot)$ are not likely to produce organic nitrates since the similar structured peroxy radicals $(\mathrm{H}(\mathrm{O}) \mathrm{CC}(\mathrm{O}) \mathrm{OO} \cdot)$, which are formed from $\mathrm{OH}$ reactions of glyoxal in the gas phase, are reported to produce neither alkyl nitrates $\left(\mathrm{H}(\mathrm{O}) \mathrm{CC}(\mathrm{O}) \mathrm{OO}+\mathrm{NO} \rightarrow \mathrm{H}(\mathrm{O}) \mathrm{CC}(\mathrm{O}) \mathrm{ONO}_{2}\right)$ nor alkyl peroxyacetyl nitrates $\left(\mathrm{H}(\mathrm{O}) \mathrm{CC}(\mathrm{O}) \mathrm{OO}+\mathrm{NO}_{2}\right.$ $\left.\rightarrow \mathrm{H}(\mathrm{O}) \mathrm{CC}(\mathrm{O}) \mathrm{OONO}_{2}\right)$, and only convert $\mathrm{NO}$ to $\mathrm{NO}_{2}$ (Orlando and Tyndall, 2001). OH radical reactions of formic acid lead to $\mathrm{CO}_{2}$ without $\mathrm{NO}_{x}$ reactions (Scheme $2 \mathrm{~b}$ ) (Atkinson et al., 2004). Therefore, glyoxylic acid is likely to be the source of peroxy radicals that convert $\mathrm{NO}$ to $\mathrm{NO}_{2}$, and organonitrates in this work are not from gas-phase formation. Since gas-phase $\mathrm{OH}$ reactions of glyoxylic acid and formic acid produce $\mathrm{HO}_{2}$ (Scheme 2a and b), this $\mathrm{HO}_{2}$ contributes to additional conversion from $\mathrm{NO}$ to $\mathrm{NO}_{2}$, and recycles $\mathrm{OH}$ (i.e., $\mathrm{HO}_{2}+\mathrm{NO} \rightarrow \mathrm{OH}+\mathrm{NO}_{2}$ ) (Orlando and 

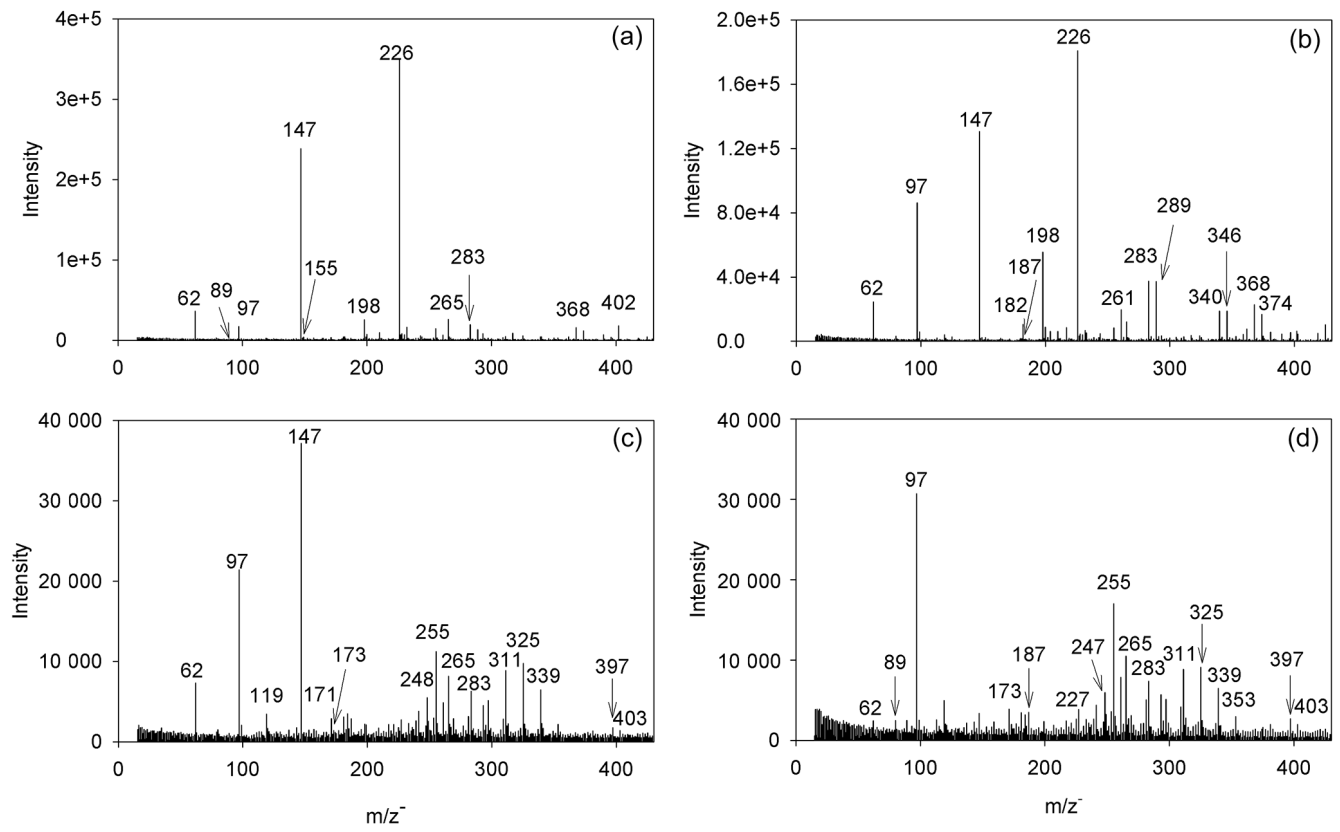

Figure 1. Negative-mode mass spectra for $3 \mathrm{~h}$ irradiated AS aerosols (a) and SA aerosols (b) in the humid chamber, and AS aerosols (c) and SA aerosols (d) in the dry chamber.

Tyndall, 2001). Lastly, $\mathrm{NO}_{2}$ reacts with $\mathrm{OH}$, forming $\mathrm{HNO}_{3}$ (Scheme 1a) (Finlayson-Pitts and Pitts Jr., 1999).

Subsequently, nitric acid is taken up into ALW. In the humid chamber, estimated ALW fractions in wet aerosols were 19.4-45.8\% for AS aerosols (experiment no. 4, Table S1 in the Supplement) and $53.1-74.2 \%$ for SA aerosols (experiment no. 12) throughout experiments, and after $3 \mathrm{~h}$ of irradiation, the peaks at $m / z^{-} 62$ (nitric acid), 147 and 226 were prominent (Fig. 1a and b). However, in the dry chamber, ALW fractions were only $\sim 1 \%$ for AS aerosols (experiment no. 1) and $26.5-32.4 \%$ (experiment no. 11) for SA aerosols. After $3 \mathrm{~h}$ of irradiation, only $m / z^{-} 62$ and 147 ( $m / z^{-} 226$ was missing) appeared with smaller intensities for AS aerosols (Fig. 1c), and none of $m / z^{-}$62, 147, and 226 appeared for SA aerosols (Fig. 1d). It is interesting that $\mathrm{HNO}_{3}$ was found in AS aerosols in the dry chamber. Formation of $\mathrm{HNO}_{3}$ by heterogeneous reactions of $\mathrm{NO}_{2}$ on the surface of aerosols has been reported previously (Crowley et al., 2010). Note, the oxidation of $\mathrm{NO}$ (and $\mathrm{NO}_{2}$ ) by $\mathrm{O}_{2}$ in the gas phase is too slow (Atkinson et al., 2004), and NO and $\mathrm{NO}_{2}$ are not very soluble for partitioning into the aqueous phase $\left(\mathrm{H}_{\mathrm{NO}}=0.019 \mathrm{M} \mathrm{atm}^{-1}, \mathrm{H}_{\mathrm{NO}_{2}}=0.007 \mathrm{M} \mathrm{atm}^{-1}\right)$. Therefore, heterogeneous reactions of $\mathrm{NO}_{2}$ on the dry surface of AS aerosols could form $\mathrm{HNO}_{3}$. No nitric acid was observed in SA aerosols, which still contain 26.5-32.4\% ALW in the dry chamber. It is possible that in the presence of sulfuric acid, nitric acid acts as a base, forming $\mathrm{NO}_{2}^{+}$and $\mathrm{HSO}_{4}^{-}$(i.e., $\mathrm{HNO}_{3}+2 \mathrm{H}_{2} \mathrm{SO}_{4} \rightarrow \mathrm{NO}_{2}^{+}+2 \mathrm{HSO}_{4}^{-}+\mathrm{H}_{3} \mathrm{O}^{+}$) (McQuarrie et al., 1991). If $\mathrm{NO}_{2}^{+}$were formed in a significant amount, it could be an important reactive species. How- ever, measurement of $\mathrm{NO}_{2}^{+}$and investigation of its potential role are beyond the scope of this study. Further studies are required for $\mathrm{HNO}_{3}$ uptake by AS and SA aerosols in the dry chamber.

Figure 2 suggests gas-phase photochemical production and uptake of $\mathrm{HNO}_{3}$ into ALW. In Fig. 2a and b, both AS and SA solutions only show sulfuric acid peaks at $m / z^{-} 97$ (monomer) and $m / z^{-} 195$ (dimer), and an organosulfate peak at $m / z^{-} 217\left(\mathrm{C}_{2} \mathrm{H}_{1} \mathrm{O}_{8} \mathrm{~S}_{2}\right)$, which is an ester product of a glyoxal and two sulfuric acids with the structure (a) and the formation (b) in Scheme 3. In the dry and dark chamber, neither nitric acid $\left(\mathrm{m} / \mathrm{z}^{-} 62\right)$ nor organonitrates $\left(\mathrm{m} / \mathrm{z}^{-} 147\right.$ and 226) were initially formed (Fig. 2c and d), suggesting little $\mathrm{HNO}_{3}$ uptake in the dry chamber. Note that in the dry chamber, ALW fractions are $1 \%$ for AS aerosols (Fig. 2c; Experiment no. 8, Table S1 in the Supplement) and $27 \%$ for SA aerosols (Fig. 2d; Experiment no. 13). Again, in the humid and dark chamber, $m / z^{-} 62,147$, and 226 initially appeared for AS and SA aerosols (Fig. 2e and f), and this is due to $\mathrm{HNO}_{3}$ uptake into sufficient ALW in both aerosols. (ALW fractions for AS and SA aerosols are $54 \%$ and $71 \%$ respectively.) However, $\mathrm{HNO}_{3}$ here is formed by dark reactions of $\mathrm{O}_{3}$ and $\mathrm{NO}_{x}$ (Scheme $1 \mathrm{~b}$ ), and disappeared in the $3 \mathrm{~h}$ dark reactions (Fig. S4 in the Supplement).

\subsection{Dilute cloud-relevant (bulk) chemistry vs. multiphase aerosol photooxidation}

The photochemistry of glyoxal in a dilute aqueous solution vessel has been established (Lim et al., 2010; Tan et al., 

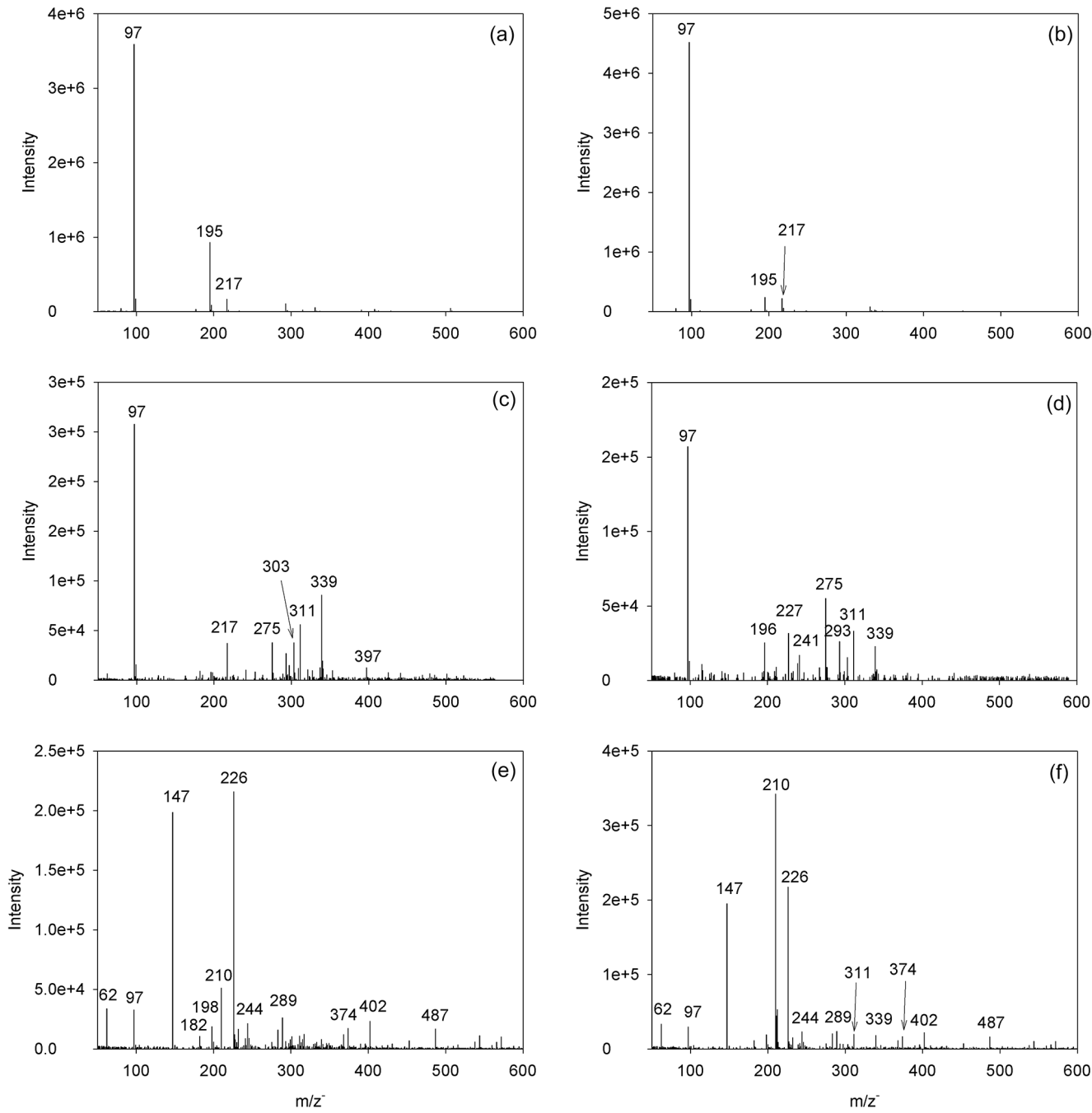

Figure 2. Negative-mode mass spectra for dark reactions of glyoxal- $\mathrm{H}_{2} \mathrm{O}_{2}-\left(\mathrm{NH}_{4}\right)_{2} \mathrm{SO}_{4}\left(\mathbf{a}\right.$, $\mathbf{c}$ and e) and glyoxal- $\mathrm{H}_{2} \mathrm{O}_{2}-\mathrm{H}_{2} \mathrm{SO}_{4}(\mathbf{b}, \mathbf{d}$ and f). Panels (a) and (b) show solutions. Panels (c) and (d) show aerosols in the dry chamber, and panels (e) and (f) are aerosols in the humid chamber at dark reaction time $=0 \mathrm{~min}$.

2010). The $\mathrm{OH}$ reaction of glyoxal in the aqueous phase mostly produces oxalic acid, with minor products like glyoxylic acid, formic acid, and carbonic acid. When the glyoxal concentration is higher than cloud-relevant concentration, tartaric acid also becomes a major product formed via organic radical-radical reactions. The reaction mechanisms including concentration-dependent pathways were elucidated, and the aqueous photochemical kinetic model (Lim et al., 2010, 2013) was developed and validated by experimental results. Assuming adequate access to $\mathrm{OH}$ radicals, the model (Perri et al., 2010) predicts that oxalic acid, tartaric acid, and organosulfates will form via radical reactions in $\mathrm{H}_{2} \mathrm{SO}_{4}$ containing wet aerosols. However, multiphase modeling suggests that depletion of $\mathrm{OH}$ radicals in wet aerosols may be substantial, and predicts that non-radical chemical pathways will dominate, leading to the formation of organosulfates (McNeill et al., 2012).

$$
\text { (b) }
$$

Scheme 3. The structure of $\mathrm{C}_{2} \mathrm{H}_{1} \mathrm{O}_{8} \mathrm{~S}_{2}$ (a) and its formation from glyoxal and sulfuric acids (b).

While sulfuric acid and ammonium hydroxide addition do not interfere with the real-time formation of oxalic acid in dilute (cloud-relevant) photooxidation experiments (bulk) (Ortiz-Montalvo et al., 2014; Tan et al., 2009), non-radical reactions with sulfate and ammonium ions dominate in 
Table 1. Elemental compositions of organic-inorganic compounds at $180 \mathrm{~min}$ irradiation time (UPLC-Q-TOF-MS negative-mode analysis).

\begin{tabular}{|c|c|c|c|c|}
\hline Aerosols (conditions) & $m / z^{-}$ & Elemental composition & Compound & Error (ppm) \\
\hline \multirow{8}{*}{ AS (humid) } & 61.9907 & $\mathrm{~N}_{1} \mathrm{O}_{3}$ & Nitric acid & 37.6 \\
\hline & 88.9840 & $\mathrm{C}_{2} \mathrm{H}_{1} \mathrm{O}_{4}$ & Oxalic acid & 45.3 \\
\hline & 96.9667 & $\mathrm{H}_{1} \mathrm{O}_{4} \mathrm{~S}_{1}$ & Sulfuric acid & 68.0 \\
\hline & $146.9669(z=2)$ & $\mathrm{C}_{6} \mathrm{H}_{2} \mathrm{~N}_{2} \mathrm{O}_{12}$ & Organonitrate & -95.5 \\
\hline & 154.9581 & $\mathrm{C}_{2} \mathrm{H}_{3} \mathrm{O}_{6} \mathrm{~S}_{1}$ & Glycolic acid-sulfate ester* & -48.3 \\
\hline & 197.9096 & $\mathrm{C}_{2} \mathrm{~N}_{1} \mathrm{O}_{8} \mathrm{~S}_{1}$ & Nitrooxy organosulfate & -128.4 \\
\hline & 225.9279 & $\mathrm{C}_{4} \mathrm{H}_{1} \mathrm{~N}_{1} \mathrm{O}_{8} \mathrm{Cl}(35) 1$ & Organonitrate & -51.9 \\
\hline & 227.9426 & $\mathrm{C}_{4} \mathrm{H}_{1} \mathrm{~N}_{1} \mathrm{O}_{8} \mathrm{Cl}(37) 1$ & & 26.0 \\
\hline \multirow{10}{*}{ SA (humid) } & 61.9911 & $\mathrm{~N}_{1} \mathrm{O}_{3}$ & Nitric acid & 44.1 \\
\hline & 96.9603 & $\mathrm{H}_{1} \mathrm{O}_{4} \mathrm{~S}_{1}$ & Sulfuric acid & 2.0 \\
\hline & $146.9665(z=2)$ & $\mathrm{C}_{6} \mathrm{H}_{2} \mathrm{~N}_{2} \mathrm{O}_{12}$ & Organonitrate & -98.2 \\
\hline & 181.9389 & $\mathrm{C}_{2} \mathrm{~N}_{1} \mathrm{O}_{7} \mathrm{~S}_{1}$ & Nitrooxy organosulfate & -6.6 \\
\hline & 186.9598 & $\mathrm{C}_{2} \mathrm{H}_{3} \mathrm{O}_{8} \mathrm{~S}_{1}$ & Oxalic acid-sulfuric acid & 23.5 \\
\hline & 197.9053 & $\mathrm{C}_{2} \mathrm{~N}_{1} \mathrm{O}_{8} \mathrm{~S}_{1}$ & Nitrooxy organosulfate & -150.1 \\
\hline & 225.9278 & $\mathrm{C}_{4} \mathrm{H}_{1} \mathrm{~N}_{1} \mathrm{O}_{8} \mathrm{Cl}(35) 1$ & Organonitrate & -52.3 \\
\hline & 227.9404 & $\mathrm{C}_{4} \mathrm{H}_{1} \mathrm{~N}_{1} \mathrm{O}_{8} \mathrm{Cl}(37) 1$ & & 16.4 \\
\hline & 282.8897 & $\mathrm{C}_{6} \mathrm{H}_{3} \mathrm{O}_{11} \mathrm{~S}_{1}$ & Organosulfate & -178.4 \\
\hline & 288.8996 & $\mathrm{C}_{6} \mathrm{H}_{1} \mathrm{O}_{10} \mathrm{~S}_{1}$ & Organosulfate & -103.8 \\
\hline \multirow{5}{*}{ AS (dry) } & 61.9925 & $\mathrm{~N}_{1} \mathrm{O}_{3}$ & Nitric acid & 66.7 \\
\hline & 96.9614 & $\mathrm{H}_{1} \mathrm{O}_{4} \mathrm{~S}_{1}$ & Sulfuric acid & 13.4 \\
\hline & $146.9677(z=2)$ & $\mathrm{C}_{6} \mathrm{H}_{2} \mathrm{~N}_{2} \mathrm{O}_{12}$ & Organonitrate & -90.1 \\
\hline & 171.0956 & $\mathrm{C}_{6} \mathrm{H}_{11} \mathrm{~N}_{4} \mathrm{O}_{2}$ & Organonitrogen & 40.0 \\
\hline & 173.0084 & $\mathrm{C}_{6} \mathrm{H}_{5} \mathrm{O}_{6}$ & Organic acid & -4.4 \\
\hline \multirow{6}{*}{ SA (dry) } & 62.0241 & $\mathrm{~N}_{1} \mathrm{O}_{3}$ & Nitric acid & -10.5 \\
\hline & 89.0389 & $\mathrm{C}_{2} \mathrm{H}_{5} \mathrm{~N}_{2} \mathrm{O}_{2}$ & Organonitrogens & 36.5 \\
\hline & 96.9604 & $\mathrm{H}_{1} \mathrm{O}_{4} \mathrm{~S}_{1}$ & Sulfuric acid & 3.1 \\
\hline & 172.9572 & $\mathrm{C}_{2} \mathrm{H}_{5} \mathrm{O}_{7} \mathrm{~S}_{1}$ & Glycolic acid-sulfuric acid & 109.5 \\
\hline & 186.9687 & $\mathrm{C}_{2} \mathrm{H}_{3} \mathrm{O}_{8} \mathrm{~S}_{1}$ & Oxalic acid-sulfuric acid & 71.1 \\
\hline & 247.0045 & $\mathrm{C}_{4} \mathrm{H}_{7} \mathrm{O}_{10} \mathrm{~S}_{1}$ & Tartaric acid-sulfuric acid & 113.2 \\
\hline
\end{tabular}

* Glycolic acid-sulfate ester was detected by Galloway et al. (2009).

AS and SA aerosols during the $3 \mathrm{~h}$ irradiation in the hu$\mathrm{mid} / \mathrm{dry}$ chamber. Mass spectral analyses in the negative mode (Fig. 1) suggest that the products are organic acids (CHO), organonitrates (CHNO), organosulfates (CHOS), and nitrooxy organosulfates (CHNOS). Proposed chemical formulae are listed in Table 1.

However, production of oxalic acid and tartaric acid provides evidence that $\mathrm{OH}$ reactions of glyoxal occurred in ALW. Note that oxalic acid cannot be formed in the gas phase since gas-phase photochemistry will decompose evaporated organic species (e.g., glyoxylic acid, formic acid) to $\mathrm{CO}_{2}$ (Scheme 2). During irradiation, oxalic acid was formed in the humid chamber, shown by UPLC-Q-TOF-MS detection of $m / z^{-} 89$ (oxalic acid) in AS aerosols (Fig. 1a) and $m / z^{-} 187$ (oxalic acid-sulfuric acid adduct) in SA aerosols (Fig. 1b). Sulfuric acid adducts to organic acid are commonly observed during aerosol nucleation and particle growth (Zhang et al., 2004). Even in the dry chamber, oxalic acid $\left(m / z^{-} 89\right)$, glycolic acid $\left(m / z^{-} 173\right.$ as a sulfuric acid adduct), and tartaric acid $\left(m / z^{-} 247\right.$ as a sulfuric acid adduct) were formed as in SA aerosols (Fig. 1d). This can be explained by the high hygroscopicity of sulfuric acid. In the dry chamber (7\% RH), SA aerosols still held $32 \%$ ALW (experiment no. 11, Table S1 in the Supplement).

The decay of glyoxal provides additional evidence that glyoxal reacts with $\mathrm{OH}$ radicals in ALW. Glyoxal is detected in the positive mode of UPLC-Q-TOF-MS. A number of peaks at $m / z^{+} 59\left(=[M+\mathrm{H}]^{+}\right), 95(=[M+$ $\left.\left.2 \mathrm{H}_{2} \mathrm{O}+\mathrm{H}\right]^{+}\right), 99\left(=\left[M+\mathrm{H}_{2} \mathrm{O}+\mathrm{Na}\right]^{+}\right), 113(=[M+$ $\left.\mathrm{MeOH}+\mathrm{Na}]^{+}\right), 117\left(=\left[M+2 \mathrm{H}_{2} \mathrm{O}+\mathrm{Na}\right]^{+}\right), 131(=[M+$ $\left.\left.\mathrm{H}_{2} \mathrm{O}+\mathrm{MeOH}+\mathrm{Na}\right]^{+}\right)$, and $145\left(=[M+2 \mathrm{MeOH}+\mathrm{Na}]^{+}\right)$ represent glyoxal in various hydrated forms and hemiacetal forms with water and methanol from the mobile phase $\left(M=\right.$ glyoxal $(\mathrm{CHO})_{2} ; \mathrm{MeOH}=$ methanol $)$ In Fig. 3, glyoxal peaks in AS aerosols and SA aerosols are plotted on a relative scale. (Glyoxal was also detected for AS aerosols in the humid chamber; however, since it was only detected in 15 and 30 min samples, no decay plot was constructed.) The relative intensity was obtained by normalizing the fraction of the raw signal intensity divided by the weight of the col- 
Table 2. Elemental compositions of glyoxal and other organic-inorganic compounds at 180 min irradiation time (UPLC-Q-TOF-MS positivemode analysis).

\begin{tabular}{|c|c|c|c|c|}
\hline Aerosols (conditions) & $m / z^{+}$ & Elemental composition & Compound & Error (ppm) \\
\hline \multirow{6}{*}{ AS (humid) } & 69.0491 & $\mathrm{C}_{3} \mathrm{H}_{5} \mathrm{~N}_{2}$ & Imidazole* & 63.4 \\
\hline & $107.9732(z=-2)$ & $\mathrm{C}_{4} \mathrm{H}_{1} \mathrm{O}_{9} \mathrm{Na}_{1}$ & Organic peroxide & -20.0 \\
\hline & 109.0698 & $\mathrm{C}_{4} \mathrm{H}_{10} \mathrm{~N}_{2} \mathrm{Na}_{1}$ & Imine & -35.0 \\
\hline & 145.0652 & $\mathrm{C}_{5} \mathrm{H}_{9} \mathrm{~N}_{2} \mathrm{O}_{3}$ & Imidazole* & 30.5 \\
\hline & 149.0299 & $\mathrm{C}_{5} \mathrm{H}_{6} \mathrm{~N}_{2} \mathrm{O}_{2} \mathrm{Na}_{1}$ & Imidazole & -72.8 \\
\hline & 203.1056 & $\mathrm{C}_{7} \mathrm{H}_{12} \mathrm{~N}_{6} \mathrm{Na}_{1}$ & Imidazole & 19.9 \\
\hline \multirow{4}{*}{ SA (humid) } & 95.0307 & $\mathrm{C}_{2} \mathrm{H}_{7} \mathrm{O}_{4}$ & Glyoxal** (dihydrated) & 33.5 \\
\hline & 98.9911 & $\mathrm{C}_{2} \mathrm{H}_{4} \mathrm{O}_{3} \mathrm{Na}_{1}$ & Glyoxal $^{* *}$ (monohydrated) & -143.1 \\
\hline & 145.0499 & $\mathrm{C}_{4} \mathrm{H}_{10} \mathrm{O}_{4} \mathrm{Na}_{1}$ & Glyoxal (hydrated by $2 \mathrm{MeOHs}$ ) & 19.1 \\
\hline & 149.0294 & $\mathrm{C}_{6} \mathrm{H}_{6} \mathrm{O}_{3} \mathrm{Na}_{1}$ & Organic compound & 56.9 \\
\hline \multirow{6}{*}{ AS (dry) } & 69.0528 & $\mathrm{C}_{3} \mathrm{H}_{5} \mathrm{~N}_{2}$ & Imidazole $^{*}$ & 116.9 \\
\hline & 113.0274 & $\mathrm{C}_{3} \mathrm{H}_{6} \mathrm{O}_{3} \mathrm{Na}_{1}$ & Glyoxal (hydrated by $1 \mathrm{MeOH}$ ) & 57.4 \\
\hline & 117.0098 & $\mathrm{C}_{2} \mathrm{H}_{4} \mathrm{O}_{6} \mathrm{Na}_{1}$ & Glyoxal (dihydrated) & -51.5 \\
\hline & 131.0348 & $\mathrm{C}_{3} \mathrm{H}_{8} \mathrm{O}_{4} \mathrm{Na}_{1}$ & Glyoxal (hydrated by $1 \mathrm{MeOH}$ ) & 25.3 \\
\hline & 149.0299 & $\mathrm{C}_{5} \mathrm{H}_{6} \mathrm{~N}_{2} \mathrm{O}_{2} \mathrm{Na}_{1}$ & Imidazole & -33.9 \\
\hline & 203.0614 & $\mathrm{C}_{7} \mathrm{H}_{11} \mathrm{~N}_{2} \mathrm{O}_{5}$ & Imidazole* & 23.9 \\
\hline \multirow{4}{*}{ SA (dry) } & 95.0415 & $\mathrm{C}_{2} \mathrm{H}_{7} \mathrm{O}_{4}$ & Glyoxal** (dihydrated) & 80.1 \\
\hline & 98.9894 & $\mathrm{C}_{2} \mathrm{H}_{4} \mathrm{O}_{3} \mathrm{Na}_{1}$ & Glyoxal** (monohydrated) & -160.3 \\
\hline & 131.0065 & $\mathrm{C}_{3} \mathrm{H}_{8} \mathrm{O}_{4} \mathrm{Na}_{1}$ & Glyoxal (hydrated by $1 \mathrm{MeOH}$ ) & -190.7 \\
\hline & 149.0213 & $\mathrm{C}_{6} \mathrm{H}_{6} \mathrm{O}_{3} \mathrm{Na}_{1}$ & Organic compound & 2.6 \\
\hline
\end{tabular}

* Imidazole detected by Kampf et al. (2012).

** Glyoxal appeared at $\mathrm{t}=0 \mathrm{~min}$, but disappeared during the irradiation.

lected particles on the filter. These estimations are not based on real-time online analyses since extracted filters were collected for $10 \mathrm{~min}$, but they still qualitatively indicate the glyoxal decay in wet aerosols. For SA aerosols, the lifetime $(\tau)$ of glyoxal in the dry chamber (51.3 min in Fig. 3a) is very similar to that in the humid chamber (54.1 min in Fig. 3b) due to the high hygroscopicity of sulfuric acid (32\% ALW in the dry chamber). Assuming no evaporation of ALW, the kinetic model (details are discussed in the next section) predicts that the lifetime of glyoxal by $\mathrm{OH}$ reactions in the aqueous phase is $5.6 \mathrm{~min}$, which is very similar to estimated values above. However, for AS aerosols in the dry chamber, glyoxal peaks at $m / z^{+} 113,117$, and 131 decay sharply in $30 \mathrm{~min}$, and the estimated lifetime is $10.9 \mathrm{~min}$ (Fig. 3c), which is $\sim 5$ times shorter than the lifetime by $\mathrm{OH}$ reactions. Since AS aerosols in the dry chamber only hold $\sim 1 \%$ ALW, this suggests that ALW evaporation affects glyoxal loss significantly. Therefore, it is possible that gas-phase glyoxal chemistry takes place during the irradiation of AS aerosols in the dry chamber since glyoxal could evaporate, too. However, gas-phase photochemistry of glyoxal produces neither oxalic acid nor organonitrates (PAN type compounds); it produces decomposed fragments (Scheme 2c) (Atkinson et al., 2006; Orlando and Tyndall, 2001).

Organonitrogens (CHNO), organosulfates (CHOS), organonitrogen sulfates (CHNOS), and organic compounds
(CHO) were also detected in the positive mode of UPLC-QTOF-MS (Table 2 and Fig. 4). Imidazoles $\left(m / z^{+} 69,145\right.$, 149, and 203) observed by Kampf et al. were also observed here in AS aerosols in the humid and dry chamber.

Organosulfates were formed in both AS and SA aerosols and detected in the negative mode of UPLC-Q-TOF-MS. The organosulfate $\left(m / z^{-} 155, \mathrm{C}_{2} \mathrm{H}_{3} \mathrm{O}_{6} \mathrm{~S}_{1}\right)$ observed by Galloway et al. was also observed in AS aerosols in the humid chamber. Galloway et al. proposed two structures for $m / z^{-} 155$, a glyoxal sulfate and a glycolic acid-sulfate ester, and we argue that it is more likely to be the glycolic acid-sulfate ester. Since $\mathrm{OH}$ reactions of glyoxal produce glycolic acid in the presence of $\mathrm{HO}_{2}$, which is commonly available during aqueous photochemistry (Lim and Turpin, 2015) (Scheme 5a), the glycolic acid-sulfate ester is formed by non-radical esterification between glycolic acid and sulfuric acid (Scheme $5 \mathrm{~b}$ ). The $m / z^{-} 173$ organosulfate $\left(\mathrm{C}_{2} \mathrm{H}_{5} \mathrm{O}_{7} \mathrm{~S}_{1}\right)$ formed in SA aerosols in the dry chamber $(7 \% \mathrm{RH}, 32 \% \mathrm{ALW})$ is likely to be a glycolic acidsulfuric acid adduct (Scheme 5c). However, the $\mathrm{m} / z^{-} 171$ (organosulfate, $\mathrm{C}_{2} \mathrm{H}_{3} \mathrm{O}_{7} \mathrm{~S}_{1}$ ), which was formed via glycolic acid radical-sulfuric acid radical reactions (Perri et al., 2010), was not observed here. This suggests that in the condensed phase, $\mathrm{OH}$ radicals mostly contribute to oxidation of organic compounds, making products that subsequently form 
Table 3. Elemental compositions of organic-inorganic compounds in dark reactions (UPLC-HR-Q-TOF-MS negative-mode analysis).

\begin{tabular}{|c|c|c|c|c|}
\hline Aerosols (conditions) & $m / z^{-}$ & Elemental composition & Compound & Error (ppm) \\
\hline \multirow{3}{*}{ AS (solution) } & 96.9596 & $\mathrm{H}_{1} \mathrm{O}_{4} \mathrm{~S}_{1}$ & Sulfuric acid & -5.2 \\
\hline & 194.9268 & $\mathrm{H}_{3} \mathrm{O}_{8} \mathrm{~S}_{2}$ & Sulfuric acid dimer & -3.5 \\
\hline & 216.9095 & $\mathrm{C} 2 \mathrm{H} 1 \mathrm{O} 8 \mathrm{~S} 2$ & Organosulfate & -10.8 \\
\hline \multirow{6}{*}{ AS (dry) } & 96.9608 & $\mathrm{H}_{1} \mathrm{O}_{4} \mathrm{~S}_{1}$ & Sulfuric acid & 7.2 \\
\hline & 216.9142 & $\mathrm{C}_{2} \mathrm{H}_{1} \mathrm{O}_{8} \mathrm{~S}_{2}$ & Organosulfate & 10.9 \\
\hline & 275.1671 & $\mathrm{C}_{13} \mathrm{H}_{23} \mathrm{O}_{6}$ & Organic acid oligomer & 62.1 \\
\hline & 311.1689 & $\mathrm{C}_{13} \mathrm{H}_{27} \mathrm{O}_{8}$ & Organic acid oligomer & -7.2 \\
\hline & 339.1974 & $\mathrm{C}_{15} \mathrm{H}_{31} \mathrm{O}_{8}$ & Organic acid oligomer & -14.9 \\
\hline & 397.0972 & $\mathrm{C}_{14} \mathrm{H}_{21} \mathrm{O}_{13}$ & Organic acid oligomer & -3.9 \\
\hline \multirow{12}{*}{ AS (humid) } & 61.9862 & $\mathrm{~N}_{1} \mathrm{O}_{3}$ & Nitric acid & -35.0 \\
\hline & 96.9603 & $\mathrm{H}_{1} \mathrm{O}_{4} \mathrm{~S}_{1}$ & Sulfuric acid & 2.0 \\
\hline & $146.9671(z=2)$ & $\mathrm{C}_{6} \mathrm{H}_{2} \mathrm{~N}_{2} \mathrm{O}_{12}$ & Organonitrate & -94.1 \\
\hline & 181.9377 & $\mathrm{C}_{2} \mathrm{~N}_{1} \mathrm{O}_{7} \mathrm{~S}_{1}$ & Nitrooxy organosulfate & -13.2 \\
\hline & 197.9200 & $\mathrm{C}_{2} \mathrm{~N}_{1} \mathrm{O}_{8} \mathrm{~S}_{1}$ & Nitrooxy organosulfate & -75.8 \\
\hline & 209.9507 & $\mathrm{C}_{3} \mathrm{~N}_{1} \mathrm{O}_{8} \mathrm{~S}_{1}$ & Nitrooxy organosulfate & 14.8 \\
\hline & 225.9276 & $\mathrm{C}_{4} \mathrm{H}_{1} \mathrm{~N}_{1} \mathrm{O}_{8} \mathrm{Cl}_{1}$ & Organonitrate & -52.7 \\
\hline & 243.9025 & $\mathrm{C}_{3} \mathrm{O}_{9} \mathrm{~S}_{2}$ & Organosulfate & 14.7 \\
\hline & 288.9074 & $\mathrm{C}_{4} \mathrm{H}_{1} \mathrm{O}_{13} \mathrm{~S}_{1}$ & Organosulfate & 24.0 \\
\hline & 373.8744 & $\mathrm{C}_{6} \mathrm{~N}_{1} \mathrm{O}_{14} \mathrm{~S}_{2}$ & Nitrooxy organosulfate & -5.8 \\
\hline & 401.9027 & $\mathrm{C}_{6} \mathrm{~N}_{3} \mathrm{O}_{16} \mathrm{~S}_{1}$ & Nitrooxy organosulfate & 5.5 \\
\hline & 486.8823 & $\mathrm{C}_{10} \mathrm{H}_{3} \mathrm{~N}_{2} \mathrm{O}_{17} \mathrm{~S}_{2}$ & Nitrooxy organosulfate & -11.1 \\
\hline \multirow{3}{*}{ SA (solution) } & 96.9614 & $\mathrm{H}_{1} \mathrm{O}_{4} \mathrm{~S}_{1}$ & Sulfuric acid & 13.4 \\
\hline & 194.9283 & $\mathrm{H}_{3} \mathrm{O}_{8} \mathrm{~S}_{2}$ & Sulfuric acid dimer & 4.2 \\
\hline & 216.9104 & $\mathrm{C}_{2} \mathrm{H}_{1} \mathrm{O}_{8} \mathrm{~S}_{2}$ & Organosulfate & -6.6 \\
\hline \multirow{5}{*}{ SA (dry) } & 96.9611 & $\mathrm{H}_{1} \mathrm{O}_{4} \mathrm{~S}_{1}$ & Sulfuric acid & 10.3 \\
\hline & 275.1615 & $\mathrm{C}_{13} \mathrm{H}_{23} \mathrm{O}_{6}$ & Organic acid oligomer & 41.7 \\
\hline & 293.1608 & $\mathrm{C}_{13} \mathrm{H}_{25} \mathrm{O}_{7}$ & Organic acid oligomer & 0.8 \\
\hline & 311.1589 & $\mathrm{C}_{13} \mathrm{H}_{27} \mathrm{O}_{8}$ & Organic acid oligomer & -39.3 \\
\hline & 339.1808 & $\mathrm{C}_{13} \mathrm{H}_{27} \mathrm{O}_{9}$ & Organic acid oligomer & -43.5 \\
\hline \multirow{12}{*}{ SA (humid) } & 61.9908 & $\mathrm{~N}_{1} \mathrm{O}_{3}$ & Nitric acid & 39.3 \\
\hline & 96.9622 & $\mathrm{H}_{1} \mathrm{O}_{4} \mathrm{~S}_{1}$ & Sulfuric acid & 21.6 \\
\hline & $146.9669(z=2)$ & $\mathrm{C}_{6} \mathrm{H}_{2} \mathrm{~N}_{2} \mathrm{O}_{12}$ & Organonitrate & -95.5 \\
\hline & 209.9499 & $\mathrm{C}_{10} \mathrm{~N}_{2} \mathrm{O}_{15} \mathrm{~S}_{1}$ & Nitrooxy organosulfate & -7.7 \\
\hline & 225.9277 & $\mathrm{C}_{4} \mathrm{H}_{1} \mathrm{~N}_{1} \mathrm{O}_{8} \mathrm{Cl} 1$ & Organonitrate & -52.7 \\
\hline & 243.9090 & $\mathrm{C}_{6} \mathrm{O}_{18} \mathrm{~S}_{4}$ & Organonitrate & 41.3 \\
\hline & 288.9016 & $\mathrm{C}_{4} \mathrm{H}_{1} \mathrm{O}_{11} \mathrm{~S}_{2}$ & Organosulfate & 17.4 \\
\hline & 311.1672 & $\mathrm{C}_{10} \mathrm{H}_{23} \mathrm{~N}_{4} \mathrm{O}_{7}$ & Organonitrate & 32.1 \\
\hline & 339.1943 & $\mathrm{C}_{12} \mathrm{H}_{27} \mathrm{~N}_{4} \mathrm{O}_{7}$ & Organonitrate & 17.0 \\
\hline & 373.8829 & $\mathrm{C}_{6} \mathrm{~N}_{1} \mathrm{O}_{14} \mathrm{~S}_{2}$ & Nitrooxy organosulfate & 16.9 \\
\hline & 401.9040 & $\mathrm{C}_{6} \mathrm{~N}_{3} \mathrm{O}_{16} \mathrm{~S}_{1}$ & Nitrooxy organosulfate & 8.8 \\
\hline & 486.8861 & $\mathrm{C}_{8} \mathrm{H}_{7} \mathrm{O}_{18} \mathrm{~S}_{3}$ & Nitrooxy organosulfate & 12.5 \\
\hline
\end{tabular}

organosulfates or organic acid-sulfuric acid adducts via nonradical reactions.

\subsection{Model simulations for smog chamber photooxidation}

In this work, aqueous glyoxal chemistry described in a previous kinetic model (Lim et al., 2010, 2013; Lim and Turpin, 2015) was expanded by including partitioning of radical ox- idants (e.g., $\mathrm{OH}$ ) and organic compounds (e.g., glyoxylic acid, formic acid) into the gas phase and the gas-phase $\mathrm{OH}$ reactions. Newly added reactions are listed in Table S3. The model was then applied to better understand the multiphase chemistry in the smog chamber experiments, including whether the proposed pathway for the production of $\mathrm{NO}_{2}$ and subsequent organonitrate formation is plausible. It is assumed that carboxylates (e.g., formate, glyoxylate, and oxalate) do not evaporate since they are likely to form 

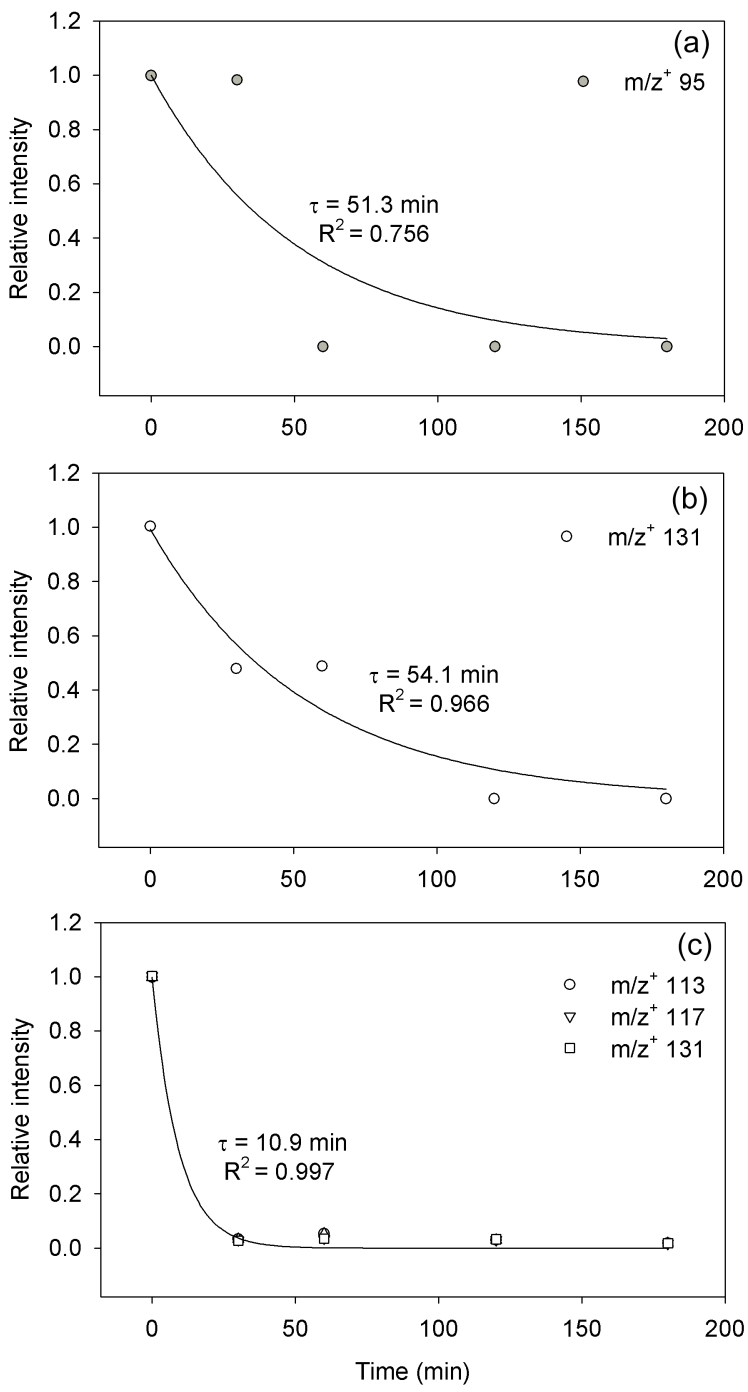

Figure 3. The decay of glyoxal in SA aerosols in the humid (a) and in the dry chamber (b), and in AS aerosols in the dry chamber (c) ( $\tau=$ lifetime).

low-volatility carboxylate salts in the atmosphere (OrtizMontalvo et al., 2012), so only undissociated acids evaporate according to water solubility. The model is not well designed to simulate the dry conditions for AS aerosols in the chamber, since water evaporation is not allowed.

With the same initial concentrations of glyoxal $(1 \mathrm{mM})$, $\mathrm{H}_{2} \mathrm{O}_{2}(200 \mu \mathrm{M})$, and $\left(\mathrm{NH}_{4}\right)_{2} \mathrm{SO}_{4}$ or $\mathrm{H}_{2} \mathrm{SO}_{4}(0.012 \mathrm{M})$, the model predicts that the dominant product is glyoxylic acid in both AS and SA aerosols in the presence of ALW (Fig. 5). In dilute (bulk) aqueous chemistry experiments designed to study chemistry in cloud water, the dominant product was found to be oxalic acid (Tan et al., 2009). However, in the chamber, where aqueous chemistry takes place in concentrated non-ideal solutions in wet aerosols with large surface area to volume ratios, oxalic acid formation was suppressed by partitioning of glyoxylic acid to (a)
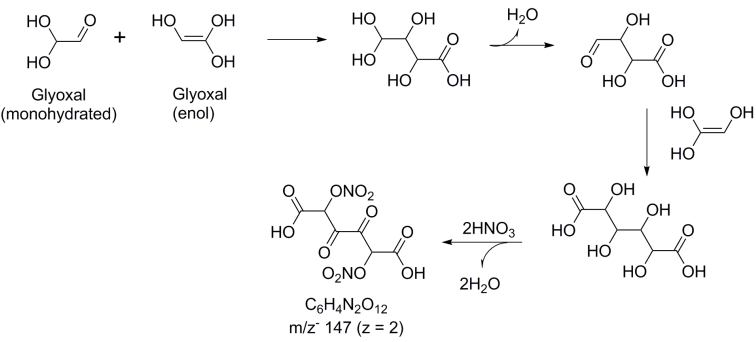
$\mathrm{C}_{6} \mathrm{H}_{4} \mathrm{~N}_{2} \mathrm{O}_{12}$
$\mathrm{~m} / \mathrm{z}^{-} 147(\mathrm{z}=2)$

(b)

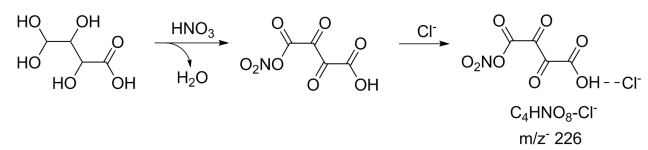

Scheme 4. Proposed formation of two organonitrates, $m / z^{-} 147$ (a) and $m / z^{-} 226$ (b).

(a)

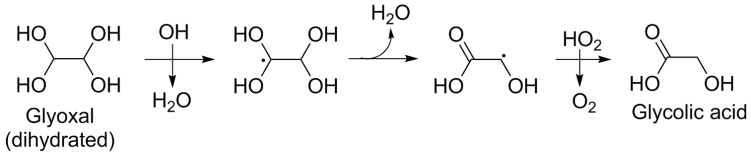

(b)

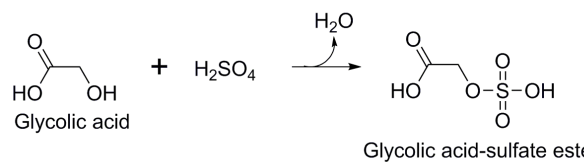

(c)

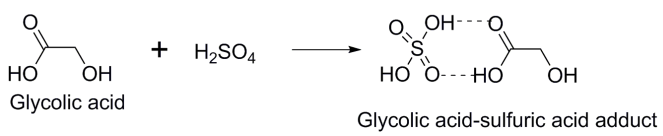

Scheme 5. Proposed glycolic acid formation from $\mathrm{OH}$ reaction of glyoxal in the aqueous phase (a), glycolic acid-sulfate ester formation from non-radical reactions of glycolic acid with sulfuric acid (b), and glycolic acid-sulfuric acid adduct formation (c).

the gas phase, consistent with predictions elsewhere (Skog et al., 2016). The concentration of gas-phase glyoxylic acid produced through AS aerosol-phase chemistry reached up to $\sim 200 \mathrm{ppb}$ from AS aerosols (Fig. 6a) and $\sim 800 \mathrm{ppb}$ from SA aerosol-phase chemistry (Fig. 6b) in the presence of ALW. Note the predicted $\mathrm{OH}$ concentration in the gas phase was $\sim 1 \times 10^{6}$ molecules $\mathrm{cm}^{-3}$, which is atmospherically relevant (Fig. S5 in the Supplement). Clearly, in the gas phase, sufficient amounts of peroxy radicals would have been formed from aqueous aerosol photochemistry to convert $\mathrm{NO}$ to $\mathrm{NO}_{2}$.

We also estimate the concentration of $\mathrm{HNO}_{3}$ taken up into wet aerosols by including chemistry of $\mathrm{NO}_{x}, \mathrm{HO}_{x}$, peroxy radical, and $\mathrm{HNO}_{3}$ partitioning $\left(H=1.6 \times 10^{5} \mathrm{M} \mathrm{atm}^{-1}\right)$ into a FACSIMILE model. $\sim 500 \mu \mathrm{M}$ of $\mathrm{HNO}_{3}$ uptake in the aqueous phase is predicted after $3 \mathrm{~h}$ of irradiation when initial conditions are $10 \mathrm{ppb}$ of $\mathrm{NO}, 0 \mathrm{ppb}$ of $\mathrm{NO}_{2}, 10 \mathrm{ppb}$ of $\mathrm{O}_{3}$, and $500 \mathrm{ppb}$ of an organic compound in the gas phase (glyoxylic acid). This concentration of $\mathrm{HNO}_{3}$ is sufficient to 

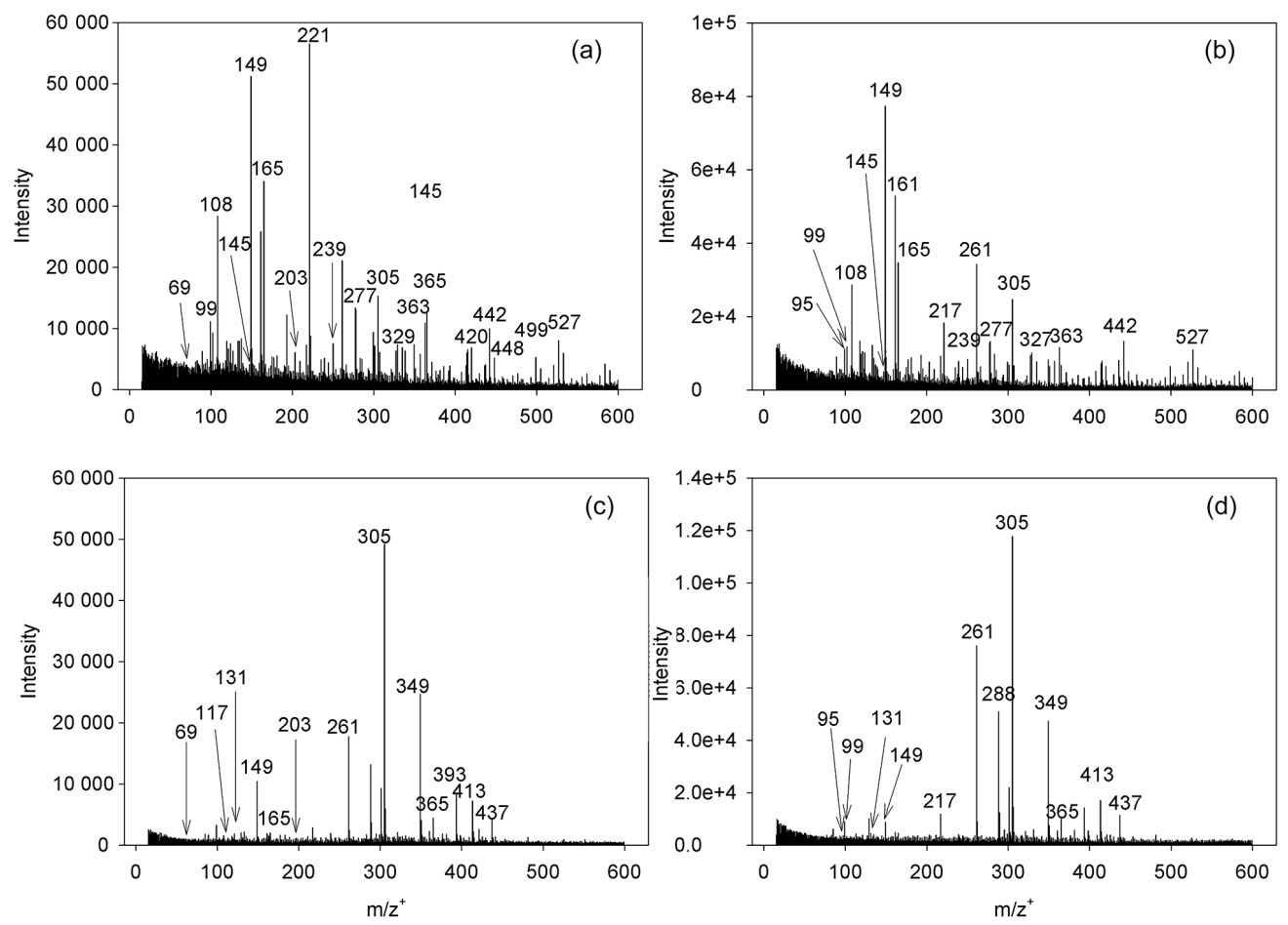

Figure 4. Positive-mode mass spectra for $3 \mathrm{~h}$ irradiated AS aerosols (a) and SA aerosols (b) in the humid chamber, and AS aerosols (c) and SA aerosols (d) in the dry chamber.

form organonitrates with glyoxal and is comparable to that of other inorganic constituents in wet aerosols $(200 \mu \mathrm{M}$ of ammonium sulfate/sulfuric acid).

\subsection{Dark aerosol-phase reactions}

AS and SA solutions, and AS and SA aerosols at $t=0 \mathrm{~min}$ in the dark chamber, were analyzed by UPLC-Q-TOFMS in the negative mode (Fig. 2). Solutions only show sulfuric acid and organosulfate (Fig. 2a and b), but atomized aerosols show many other peaks including organic acids (CHO), organosulfates (CHOS), nitric acids $\left(\mathrm{HNO}_{3}\right)$, organonitrogens $(\mathrm{CHNO})$, and organonitrogen sulfates (CHNOS) (Fig. 2c, d, e and f). When the solutions are atomized and introduced into the smog chamber, water evaporates to equilibrate to the chamber RH, and concentrations of solutes increase. Water loss and concentration increase result in the formation of oligomers and inorganic products. Glyoxal forms oligomers via hemiacetal formation, and aldol-condensation can lead organic acid products (Lim et al., 2010; Loeffler et al., 2006; Sareen et al., 2010). Generally, organic acid oligomers (CHO) were formed in the dry chamber, and inorganic compounds and oligomers (CHNO, CHNOS) in the humid chamber (Proposed molecular formula are listed in Table 3). It appears that acid catalysis (aldol condensation and hemiacetal formation) leading to organic acid formation favors low ALW and high acid- ity because a hydrated glyoxal in the aqueous phase will be partially dehydrated to form an aldehyde group, and the dehydration can be maximized by the evaporation of ALW in the dry chamber (Lim et al., 2010). However, acidity effects on oligomer formation require further study because sulfuric acid in SA aerosols appears to enhance oligomerization, while photochemically formed nitric acid does not. As discussed in Sect. 3.1, the prominent peaks represent nitric acid $\left(m / z^{-}\right.$62) and organonitrates $\left(m / z^{-} 147\right.$ and 226) for both AS and SA aerosols in the humid dark chamber (Fig. 2e and f). In the dark, nitric acid is formed by $\mathrm{N}_{2} \mathrm{O}_{5}$ uptake by water, and the gas-phase reaction of $\mathrm{NO}_{2}$ and $\mathrm{NO}_{3}$ produces $\mathrm{N}_{2} \mathrm{O}_{5}$ (Scheme 1b) (Finlayson-Pitts and Pitts Jr., 1999). Dark experiments were conducted initially with $\mathrm{NO}$ and $\mathrm{O}_{3}$ available, so $\mathrm{NO}_{2}$ and $\mathrm{NO}_{3}$ were probably formed by the $\mathrm{O}_{3}$ oxidation of $\mathrm{NO}$ and $\mathrm{NO}_{2}$, respectively (Scheme $1 \mathrm{~b}$ ).

After $1 \mathrm{~h}$ of dark reactions, $m / z^{-} 62,147$, and 226 disappeared in AS and SA aerosols in the humid chamber (Fig. S4 in the Supplement). $\mathrm{NO}_{x}$ and $\mathrm{O}_{3}$ levels stayed almost the same, indicating little $\mathrm{HNO}_{3}$ formation in the dark. Instead, many other $m / z^{-}$peaks appeared, indicating that various non-radical reactions had taken place. Non-radical reactions also occurred in the dry chamber.

In the positive-mode mass spectra for the AS solution, imidazole $\left(m / z^{+} 69\right)$, glyoxal $\left(m / z^{+} 117\right)$, and imines $\left(m / z^{+}\right.$ 133, 248, and 363) were detected (Fig. S6a in the Supplement), while high molecular weight organic compounds, 

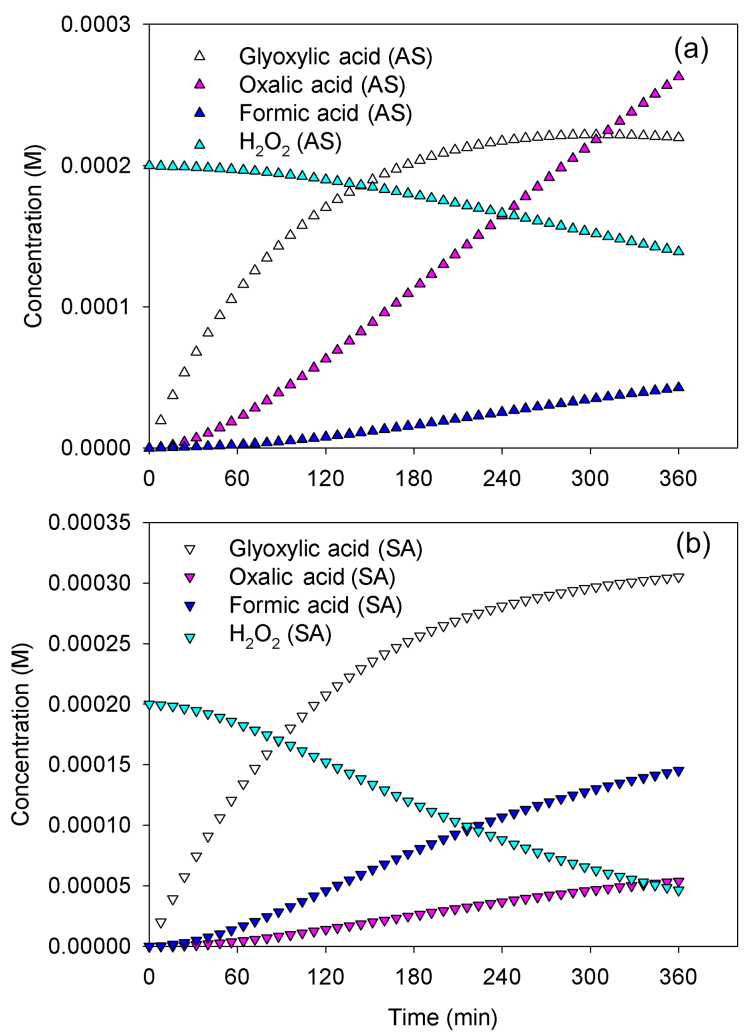

Figure 5. Simulated concentrations in ALW of AS aerosols (a) and SA aerosols (b) during $3 \mathrm{~h}$ irradiation in the humid chamber.

which are presumably acid-catalyzed products from glyoxal, were detected in the SA solution (Fig. S6b). Many more peaks are found in the mass spectra of AS and SA aerosols (Fig. S6c, d, e, and $\mathrm{f}$ in the Supplement) than the solutions. Proposed elemental compositions based on MIDAS are listed in Table S2 in the Supplement. All organonitrogens in the positive mode for AS aerosols are expected to be imines because aqueous-phase reactions of glyoxal with ammonium form imines (Galloway et al., 2009; Noziere et al., 2009; $\mathrm{Yu}$ et al., 2011). Organic compounds (CHO) are oligomers of glyoxal, which are mostly detected in SA aerosols, while imines (CHNO) are prominent in AS aerosols.

After $1 \mathrm{~h}$ dark reactions, oligomerization was evident in the positive-mode mass spectra from dark experiments (Fig. S7 in the Supplement). It appears that in AS aerosols, ammonium ions form oligomers and imines. In SA aerosols, the formation of oligomers and organosulfates are enhanced by sulfuric acid. This is consistent with the previous observation of oligomer formation for IEPOX (Nguyen et al., 2014). When ALW is sufficient (in AS aerosols in the humid chamber and SA aerosols in the humid/dry chamber), mass spectra are similar (Fig. S7a, b, and d in the Supplement), in which unidentified peaks at $m / z^{+}$99, 261, 299, 301, and 305 are dominant, indicating that products of multiphase aerosol reactions are different from those of heterogeneous reactions
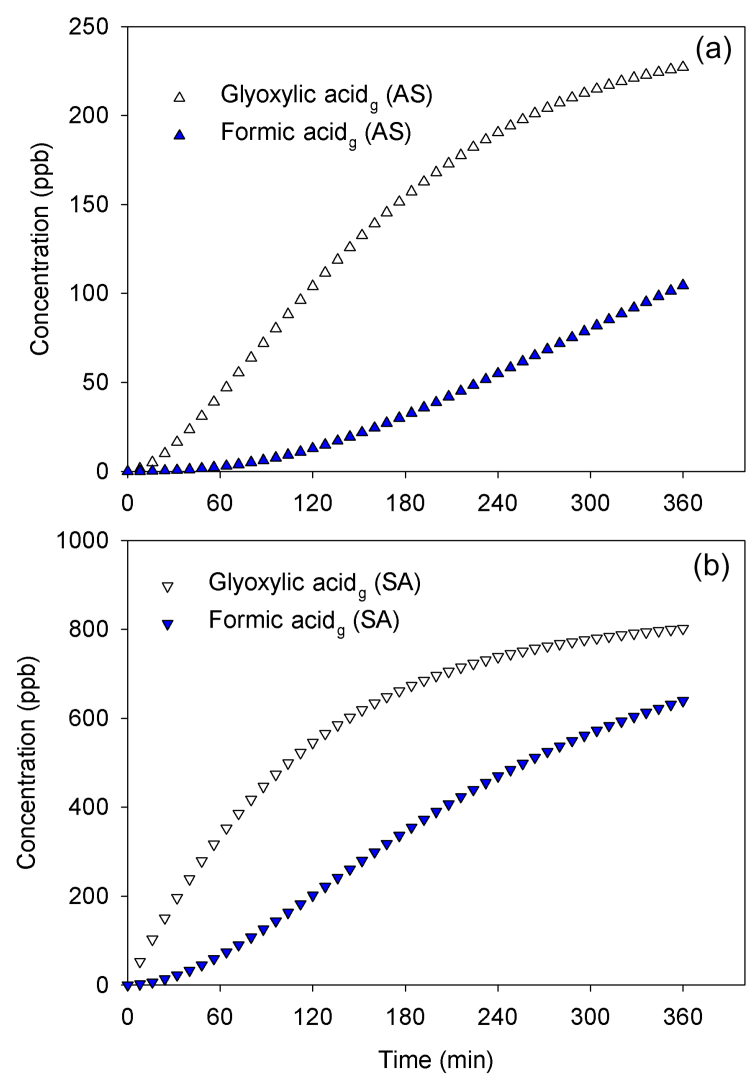

Figure 6. Gas-phase simulations of glyoxylic acid and formic acid evaporated from AS aerosols (a) and SA aerosols (b) during $3 \mathrm{~h}$ irradiation in the humid chamber.

on the dry aerosol surface (AS aerosols in the dry chamber; Fig. S7c in the Supplement). Further studies are required for surface and multiphase chemistry affected by hygroscopicity and acidity of aerosols and RH.

\section{Conclusions and atmospheric implications}

This work demonstrates $\mathrm{HNO}_{3}$ uptake by wet aerosols and formation of organonitrates with water-soluble organic constituents via aqueous chemistry, which to our knowledge has not been reported previously. Our main conclusion is that organonitrates can be formed in wet aerosols during the daytime in the presence of $\mathrm{NO}_{x}$ in humid areas. Hydrogen peroxide is an $\mathrm{OH}$ radical source, and its presence in wet aerosols can be expected when $\sim$ ppb is available in the gas phase. $\mathrm{HNO}_{3}$ formation is facilitated by aqueous photooxidation: $\mathrm{NO}$ is effectively converted to $\mathrm{NO}_{2}$ by volatile organic products (glyoxylic acids) during aqueous photooxidation; and $\mathrm{OH}$ generated in wet aerosols by photolysis of hydrogen peroxide evaporates and forms $\mathrm{HNO}_{3}$ with $\mathrm{NO}_{2} . \mathrm{HNO}_{3}$ then forms organonitrates with aldehydes and alcohols, dominant water-soluble organic species in wet aerosols. This chemistry is inherently multiphase chemistry. Organonitrates formed in 
aerosol waters are not likely alkyl nitrates formed by peroxy radical reactions with $\mathrm{NO}$ in the gas phase, followed by gas-particle partitioning (Lee et al., 2016) because yields of alkyl nitrates in alkane- $\mathrm{OH}-\mathrm{NO}_{x}$ chamber experiments decreased in humid conditions due to hydrophobicity (Lim and Ziemann, 2009). In order to be hydrophilic, VOCs must contain a small number of carbons. This small size also facilitates uptake into wet aerosols. The reaction of peroxy radicals with NO favors alkoxy radical formation, and suppresses alkyl nitrate formation (Arey et al., 2001). In our irradiated chamber, this organonitrate chemistry was facilitated by gas-phase VOC- $\mathrm{NO}_{x}-\mathrm{O}_{3}$ photochemistry (Table $\mathrm{S} 1$ in the Supplement), forming $\mathrm{HNO}_{3}$. This represents typical anthropogenic photochemistry of $\mathrm{VOC}-\mathrm{NO}_{x}-\mathrm{O}_{3}$, leading to $\mathrm{HNO}_{3}$ formation as a sink (Finlayson-Pitts and Pitts Jr., 1999). Note that concentrations of glyoxal and hydrogen peroxide in atomized solutions are atmospherically relevant (Guo et al., 2014; Lim et al., 2013).

Nitrates are major constituents in atmospheric aerosols (Zhang et al., 2007). They are very hygroscopic, facilitating water uptake into aerosols (Hennigan et al., 2008a; Hodas et al., 2014). ALW in turn facilitates aerosol partitioning of $\mathrm{HNO}_{3}$. Field observations support $\mathrm{HNO}_{3}$ uptake by aerosol waters during the daytime (Allen et al., 2015; Hodas et al., 2014). Notably, nitrate concentrations are strongly correlated with water-soluble organic compound concentrations (Hennigan et al., 2008b). This study suggests that highly oxidized organonitrates are formed in wet aerosols. An understanding of their contribution to overall atmospheric organonitrate particulate mass warrants further study.

\section{The Supplement related to this article is available online at doi:10.5194/acp-16-12631-2016-supplement.}

Acknowledgements. This work was supported by Brainpool Fellowship from the Ministry of Science, ICT and Future Planning, Republic of Korea (152S-5-2-1416), and the Korea Institute of Science and Technology. The authors acknowledge Minsuk Oh and Hyunmi Park at the Mass Spectrometry Division of the KIST Chemical Analysis Center for UPLC-HR-Q-TOF-MS analysis. The authors thank Jino Kim for laboratory assistance. The authors also thank Frank N. Keutsch for helpful discussions. Barbara J. Turpin gratefully acknowledges support from the US National Science Foundation (no. 10526611).

Edited by: R. Cohen

Reviewed by: three anonymous referees

\section{References}

Allen, H. M., Draper, D. C., Ayres, B. R., Ault, A., Bondy, A., Takahama, S., Modini, R. L., Baumann, K., Edgerton, E., Knote,
C., Laskin, A., Wang, B., and Fry, J. L.: Influence of crustal dust and sea spray supermicron particle concentrations and acidity on inorganic $\mathrm{NO}_{3}^{-}$aerosol during the 2013 Southern Oxidant and Aerosol Study, Atmos. Chem. Phys., 15, 10669-10685, doi:10.5194/acp-15-10669-2015, 2015.

Altieri, K. E., Seitzinger, S. P., Carlton, A. G., Turpin, B. J., Klein, G. C., and Marshall, A. G.: Oligomers formed through in-cloud methylglyoxal reactions: Chemical composition, properties, and mechanisms investigated by ultra-high resolution FT-ICR mass spectrometry, Atmos. Environ., 42, 1476-1490, doi:10.1016/j.atmosenv.2007.11.015, 2008.

Altieri, K. E., Turpin, B. J., and Seitzinger, S. P.: Oligomers, organosulfates, and nitrooxy organosulfates in rainwater identified by ultra-high resolution electrospray ionization FTICR mass spectrometry, Atmos. Chem. Phys., 9, 2533-2542, doi:10.5194/acp-9-2533-2009, 2009.

Arakaki, T., Anastasio, C., Kuroki, Y., Nakajima, H., Okada, K., Kotani, Y., Handa, D., Azechi, S., Kimura, T., Tsuhako, A., and Miyagi, Y.: A General Scavenging Rate Constant for Reaction of Hydroxyl Radical with Organic Carbon in Atmospheric Waters, Environ. Sci. Technol., 47, 8196-8203, doi:10.1021/es401927b, 2013.

Arey, J., Aschmann, S. M., Kwok, E. S. C., and Atkinson, R.: Alkyl Nitrate, Hydroxyalkyl Nitrate, and Hydroxycarbonyl Formation from the NOx-Air Photooxidations of C5-C8 n-Alkanes, J. Phys. Chem. A, 105, 1020-1027, doi:10.1021/jp003292z, 2001.

Atkinson, R. and Arey, J.: Atmospheric degradation of volatile organic compounds, Chem. Rev., 103, 4605-4638, doi:10.1021/cr0206420, 2003.

Atkinson, R., Baulch, D. L., Cox, R. A., Crowley, J. N., Hampson, R. F., Hynes, R. G., Jenkin, M. E., Rossi, M. J., and Troe, J.: Evaluated kinetic and photochemical data for atmospheric chemistry: Volume $\mathrm{I}-$ gas phase reactions of $\mathrm{O}_{\mathrm{x}}, \mathrm{HO}_{\mathrm{x}}, \mathrm{NO}_{\mathrm{x}}$ and $\mathrm{SO}_{\mathrm{x}}$ species, Atmos. Chem. Phys., 4, 1461-1738, doi:10.5194/acp-41461-2004, 2004.

Atkinson, R., Baulch, D. L., Cox, R. A., Crowley, J. N., Hampson, R. F., Hynes, R. G., Jenkin, M. E., Rossi, M. J., Troe, J., and IUPAC Subcommittee: Evaluated kinetic and photochemical data for atmospheric chemistry: Volume II - gas phase reactions of organic species, Atmos. Chem. Phys., 6, 3625-4055, doi:10.5194/acp-6-3625-2006, 2006.

Blando, J. D. and Turpin, B. J.: Secondary organic aerosol formation in cloud and fog droplets: a literature evaluation of plausibility, Atmos. Environ., 34, 1623-1632, doi:10.1016/s13522310(99)00392-1, 2000.

Boone, E. J., Laskin, A., Laskin, J., Wirth, C., Shepson, P. B., Stirm, B. H., and Pratt, K. A.: Aqueous Processing of Atmospheric Organic Particles in Cloud Water Collected via Aircraft Sampling, Environ. Sci. Technol., 49, 8523-8530, doi:10.1021/acs.est.5b01639, 2015.

Boschan, R., Merrow, R. T., and van Dolah, R. W.: The Chemistry of Nitrate Esters, Chem. Rev., 55, 485-510, doi:10.1021/cr50003a001, 1955.

Bouma, W. J. and Jennings, K. R.: Negative chemical ionization mass spectrometry of explosives, Org. Mass Spectrom., 16, 331335, doi:10.1002/oms.1210160802, 1981.

Carlton, A. G. and Turpin, B. J.: Particle partitioning potential of organic compounds is highest in the Eastern US and driven by 
anthropogenic water, Atmos. Chem. Phys., 13, 10203-10214, doi:10.5194/acp-13-10203-2013, 2013.

Chebbi, A. and Carlier, P.: Carboxylic acids in the troposphere, occurrence, sources, and sinks: A review, Atmos. Environ., 30, 4233-4249, doi:10.1016/1352-2310(96)00102-1, 1996.

Connelly, B. M., De Haan, D. O., and Tolbert, M. A.: Heterogeneous Glyoxal Oxidation: A Potential Source of Secondary Organic Aerosol, J. Phys. Chem. A, 116, 6180-6187, doi:10.1021/jp211502e, 2012.

Corrigan, A. L., Hanley, S. W., and De Haan, D. O.: Uptake of Glyoxal by Organic and Inorganic Aerosol, Environ. Sci. Technol., 42, 4428-4433, doi:10.1021/es7032394, 2008.

Crowley, J. N., Ammann, M., Cox, R. A., Hynes, R. G., Jenkin, M. E., Mellouki, A., Rossi, M. J., Troe, J., and Wallington, T. J.: Evaluated kinetic and photochemical data for atmospheric chemistry: Volume V - heterogeneous reactions on solid substrates, Atmos. Chem. Phys., 10, 9059-9223, doi:10.5194/acp-10-90592010, 2010.

Drozd, G., Woo, J., Häkkinen, S. A. K., Nenes, A., and McNeill, V. F.: Inorganic salts interact with oxalic acid in submicron particles to form material with low hygroscopicity and volatility, Atmos. Chem. Phys., 14, 5205-5215, doi:10.5194/acp-14-52052014, 2014

El-Sayed, M. M. H., Wang, Y., and Hennigan, C. J.: Direct atmospheric evidence for the irreversible formation of aqueous secondary organic aerosol, Geophys. Res. Lett., 42, 5577-5586, doi:10.1002/2015GL064556, 2015.

Ervens, B. and Volkamer, R.: Glyoxal processing by aerosol multiphase chemistry: towards a kinetic modeling framework of secondary organic aerosol formation in aqueous particles, Atmos. Chem. Phys., 10, 8219-8244, doi:10.5194/acp-10-8219-2010, 2010.

Ervens, B., Turpin, B. J., and Weber, R. J.: Secondary organic aerosol formation in cloud droplets and aqueous particles (aqSOA): a review of laboratory, field and model studies, Atmos. Chem. Phys., 11, 11069-11102, doi:10.5194/acp-1111069-2011, 2011.

Ervens, B., Sorooshian, A., Lim, Y. B., and Turpin, B. J.: Key parameters controlling $\mathrm{OH}$-initiated formation of secondary organic aerosol in the aqueous phase (aqSOA), J. Geophys. Res. Atmos., 119, 3997-4016, doi:10.1002/2013JD021021, 2014.

Finlayson-Pitts, B. J. and Pitts Jr., J. N.: Chemistry of the upper and lower atmosphere: theory, experiments, and applications, Academic Press, 1999.

Galloway, M. M., Chhabra, P. S., Chan, A. W. H., Surratt, J. D., Flagan, R. C., Seinfeld, J. H., and Keutsch, F. N.: Glyoxal uptake on ammonium sulphate seed aerosol: reaction products and reversibility of uptake under dark and irradiated conditions, Atmos. Chem. Phys., 9, 3331-3345, doi:10.5194/acp-9-3331-2009, 2009.

Gilardoni, S., Massoli, P., Paglione, M., Giulianelli, L., Carbone, C., Rinaldi, M., Decesari, S., Sandrini, S., Costabile, F., Gobbi, G. P., Pietrogrande, M. C., Visentin, M., Scotto, F., Fuzzi, S., and Facchini, M. C.: Direct observation of aqueous secondary organic aerosol from biomass-burning emissions, P. Natl. Acad. Sci., 113, 10013-10018, doi:10.1073/pnas.1602212113, 2016.

Gong, W., Stroud, C., and Zhang, L.: Cloud Processing of Gases and Aerosols in Air Quality Modeling, Atmosphere, 2, 567-616, doi:10.3390/atmos2040567, 2011.
Guo, J., Tilgner, A., Yeung, C., Wang, Z., Louie, P. K. K., Luk, C. W. Y., Xu, Z., Yuan, C., Gao, Y., Poon, S., Herrmann, H., Lee, S., Lam, K. S., and Wang, T.: Atmospheric Peroxides in a Polluted Subtropical Environment: Seasonal Variation, Sources and Sinks, and Importance of Heterogeneous Processes, Environ. Sci. Technol., 48, 1443-1450, doi:10.1021/es403229x, 2014.

Guzman, M. I., Colussi, A. J., and Hoffmann, M. R.: Photoinduced oligomerization of aqueous pyruvic acid, J. Phys. Chem. A, 110, 3619-3626, doi:10.1021/jp056097z, 2006.

Hennigan, C. J., Bergin, M. H., Dibb, J. E., and Weber, R. J.: Enhanced secondary organic aerosol formation due to water uptake by fine particles, Geophys. Res. Lett., 35, doi:10.1029/2008GL035046, doi:10.1029/2008GL035046, 2008a.

Hennigan, C. J., Sullivan, A. P., Fountoukis, C. I., Nenes, A., Hecobian, A., Vargas, O., Peltier, R. E., Case Hanks, A. T., Huey, L. G., Lefer, B. L., Russell, A. G., and Weber, R. J.: On the volatility and production mechanisms of newly formed nitrate and water soluble organic aerosol in Mexico City, Atmos. Chem. Phys., 8, 3761-3768, doi:10.5194/acp-8-3761-2008, 2008b.

Hodas, N., Sullivan, A. P., Skog, K., Keutsch, F. N., Collett, J. L., Decesari, S., Facchini, M. C., Carlton, A. G., Laaksonen, A., and Turpin, B. J.: Aerosol Liquid Water Driven by Anthropogenic Nitrate: Implications for Lifetimes of Water-Soluble Organic Gases and Potential for Secondary Organic Aerosol Formation, Environ. Sci. Technol., 48, 11127-11136, doi:10.1021/es5025096, 2014.

Jang, M. S., Czoschke, N. M., Lee, S., and Kamens, R. M.: Heterogeneous atmospheric aerosol production by acidcatalyzed particle-phase reactions, Science, 298, 814-817, doi:10.1126/science.1075798, 2002.

Kalberer, M., Paulsen, D., Sax, M., Steinbacher, M., Dommen, J., Prevot, A. S. H., Fisseha, R., Weingartner, E., Frankevich, V., Zenobi, R., and Baltensperger, U.: Identification of polymers as major components of atmospheric organic aerosols, Science, 303, 1659-1662, doi:10.1126/science.1092185, 2004.

Kampf, C. J., Jakob, R., and Hoffmann, T.: Identification and characterization of aging products in the glyoxal/ammonium sulfate system - implications for light-absorbing material in atmospheric aerosols, Atmos. Chem. Phys., 12, 6323-6333, doi:10.5194/acp-12-6323-2012, 2012.

Kirkland, J. R., Lim, Y. B., Tan, Y., Altieri, K. E., and Turpin, B. J.: Glyoxal secondary organic aerosol chemistry: effects of dilute nitrate and ammonium and support for organic radicalradical oligomer formation, Environ. Chem., 10, 158-166, doi:10.1071/EN13074, 2013.

Lawrence, A. H., Neudorfl, P., and Stone, J. A.: The formation of chloride adducts in the detection of dinitro-compounds by ion mobility spectrometry, Int. J. Mass spectrom., 209, 185-195, doi:10.1016/S1387-3806(01)00497-3, 2001.

Lee, A. K. Y., Herckes, P., Leaitch, W. R., Macdonald, A. M., and Abbatt, J. P. D.: Aqueous $\mathrm{OH}$ oxidation of ambient organic aerosol and cloud water organics: Formation of highly oxidized products, Geophys. Res. Lett., 38, doi:10.1029/2011g1047439, 2011.

Lee, A. K. Y., Hayden, K. L., Herckes, P., Leaitch, W. R., Liggio, J., Macdonald, A. M., and Abbatt, J. P. D.: Characterization of aerosol and cloud water at a mountain site during WACS 2010: secondary organic aerosol formation through ox- 
idative cloud processing, Atmos. Chem. Phys., 12, 7103-7116, doi:10.5194/acp-12-7103-2012, 2012.

Lee, B. H., Mohr, C., Lopez-Hilfiker, F. D., Lutz, A., Hallquist, M., Lee, L., Romer, P., Cohen, R. C., Iyer, S., Kurtén, T., Hu, W., Day, D. A., Campuzano-Jost, P., Jimenez, J. L., Xu, L., Ng, N. L., Guo, H., Weber, R. J., Wild, R. J., Brown, S. S., Koss, A., de Gouw, J., Olson, K., Goldstein, A. H., Seco, R., Kim, S., McAvey, K., Shepson, P. B., Starn, T., Baumann, K., Edgerton, E. S., Liu, J., Shilling, J. E., Miller, D. O., Brune, W., Schobesberger, S., D'Ambro, E. L., and Thornton, J. A.: Highly functionalized organic nitrates in the southeast United States: Contribution to secondary organic aerosol and reactive nitrogen budgets, P. Natl. Acad. Sci., 113, 1516-1521, doi:10.1073/pnas.1508108113, 2016.

Liao, H. and Seinfeld, J. H.: Global impacts of gas-phase chemistryaerosol interactions on direct radiative forcing by anthropogenic aerosols and ozone, J. Geophys. Res. Atmos., 110, D18208, doi:10.1029/2005JD005907, 2005.

Liggio, J., Li, S.-M., and McLaren, R.: Reactive uptake of glyoxal by particulate matter, J. Geophys. Res. Atmos., 110, D10304, doi:10.1029/2004JD005113, 2005.

Lim, Y. B. and Turpin, B. J.: Laboratory evidence of organic peroxide and peroxyhemiacetal formation in the aqueous phase and implications for aqueous $\mathrm{OH}$, Atmos. Chem. Phys., 15, 1286712877, doi:10.5194/acp-15-12867-2015, 2015.

Lim, Y. B. and Ziemann, P. J.: Chemistry of Secondary Organic Aerosol Formation from $\mathrm{OH}$ Radical-Initiated Reactions of Linear, Branched, and Cyclic Alkanes in the Presence of $\mathrm{NO}_{x}$, Aerosol Sci. Technol., 43, 604-619, doi:10.1080/02786820902802567, 2009.

Lim, Y. B., Tan, Y., Perri, M. J., Seitzinger, S. P., and Turpin, B. J.: Aqueous chemistry and its role in secondary organic aerosol (SOA) formation, Atmos. Chem. Phys., 10, 1052110539, doi:10.5194/acp-10-10521-2010, 2010.

Lim, Y. B., Tan, Y., and Turpin, B. J.: Chemical insights, explicit chemistry, and yields of secondary organic aerosol from $\mathrm{OH}$ radical oxidation of methylglyoxal and glyoxal in the aqueous phase, Atmos. Chem. Phys., 13, 8651-8667, doi:10.5194/acp-13-86512013, 2013.

Lin, G., Penner, J. E., Sillman, S., Taraborrelli, D., and Lelieveld, J.: Global modeling of SOA formation from dicarbonyls, epoxides, organic nitrates and peroxides, Atmos. Chem. Phys., 12, 47434774, doi:10.5194/acp-12-4743-2012, 2012.

Liu, J., Horowitz, L. W., Fan, S., Carlton, A. G., and Levy II, H.: Global in-cloud production of secondary organic aerosols: Implementation of a detailed chemical mechanism in the GFDL atmospheric model AM3, J. Geophys. Res.-Atmos., 117, D15303, doi:10.1029/2012JD017838, 2012a.

Liu, Y., Monod, A., Tritscher, T., Praplan, A. P., DeCarlo, P. F., Temime-Roussel, B., Quivet, E., Marchand, N., Dommen, J., and Baltensperger, U.: Aqueous phase processing of secondary organic aerosol from isoprene photooxidation, Atmos. Chem. Phys., 12, 5879-5895, doi:10.5194/acp-12-5879-2012, 2012 b.

Loeffler, K. W., Koehler, C. A., Paul, N. M., and De Haan, D. O.: Oligomer formation in evaporating aqueous glyoxal and methyl glyoxal solutions, Environ. Sci. Technol., 40, 6318-6323, doi:10.1021/es060810w, 2006.

McNeill, V. F., Woo, J. L., Kim, D. D., Schwier, A. N., Wannell, N. J., Sumner, A. J., and Barakat, J. M.: Aqueous-Phase Secondary
Organic Aerosol and Organosulfate Formation in Atmospheric Aerosols: A Modeling Study, Environ. Sci. Technol., 46, 80758081, doi:10.1021/es3002986, 2012.

McQuarrie, D. A., Rock, P. A., and Gallogly, E. B.: General chemistry, WH Freeman New York, 1991.

Myriokefalitakis, S., Tsigaridis, K., Mihalopoulos, N., Sciare, J., Nenes, A., Kawamura, K., Segers, A., and Kanakidou, M.: Incloud oxalate formation in the global troposphere: a 3-D modeling study, Atmos. Chem. Phys., 11, 5761-5782, doi:10.5194/acp11-5761-2011, 2011.

Nguyen, T. B., Coggon, M. M., Flagan, R. C., and Seinfeld, J. H.: Reactive Uptake and Photo-Fenton Oxidation of Glycolaldehyde in Aerosol Liquid Water, Environ. Sci. Technol., 47, 4307-4316, doi:10.1021/es400538j, 2013.

Nguyen, T. B., Coggon, M. M., Bates, K. H., Zhang, X., Schwantes, R. H., Schilling, K. A., Loza, C. L., Flagan, R. C., Wennberg, P. O., and Seinfeld, J. H.: Organic aerosol formation from the reactive uptake of isoprene epoxydiols (IEPOX) onto nonacidified inorganic seeds, Atmos. Chem. Phys., 14, 3497-3510, doi:10.5194/acp-14-3497-2014, 2014.

Noziere, B. and Cordova, A.: A kinetic and mechanistic study of the amino acid catalyzed aldol condensation of acetaldehyde in aqueous and salt solutions, J. Phys. Chem. A, 112, 2827-2837, doi:10.1021/jp7096845, 2008.

Noziere, B., Dziedzic, P., and Cordova, A.: Products and Kinetics of the Liquid-Phase Reaction of Glyoxal Catalyzed by Ammonium Ions $\left(\mathrm{NH}_{4}^{+}\right)$, J. Phys. Chem. A, 113, 231-237, doi:10.1021/jp8078293, 2009.

Odum, J. R., Hoffmann, T., Bowman, F., Collins, D., Flagan, R. C., and Seinfeld, J. H.: Gas/particle partitioning and secondary organic aerosol yields, Environ. Sci. Technol., 30, 2580-2585, doi:10.1021/Es950943+, 1996.

Orlando, J. J. and Tyndall, G. S.: The atmospheric chemistry of the $\mathrm{HC}(\mathrm{O}) \mathrm{CO}$ radical, Int. J. Chem. Kinet., 33, 149-156, doi:10.1002/1097-4601(200103)33:3<149::AIDKIN1008>3.0.CO;2-1, 2001.

Ortiz-Montalvo, D. L., Lim, Y. B., Perri, M. J., Seitzinger, S. P., and Turpin, B. J.: Volatility and Yield of Glycolaldehyde SOA Formed through Aqueous Photochemistry and Droplet Evaporation, Aerosol Sci. Technol., 46, 1002-1014, doi:10.1080/02786826.2012.686676, 2012.

Ortiz-Montalvo, D. L., Hakkinen, S. A. K., Schwier, A. N., Lim, Y. B., McNeill, V. F., and Turpin, B. J.: Ammonium Addition (and Aerosol pH) Has a Dramatic Impact on the Volatility and Yield of Glyoxal Secondary Organic Aerosol, Environ. Sci. Technol., 48, 255-262, doi:10.1021/es4035667, 2014.

Paciga, A. L., Riipinen, I., and Pandis, S. N.: Effect of Ammonia on the Volatility of Organic Diacids, Environ. Sci. Technol., 48, 13769-13775, doi:10.1021/es5037805, 2014.

Pankow, J. F.: An Absorption-Model of the Gas Aerosol Partitioning Involved in the Formation of Secondary Organic Aerosol, Atmos. Environ., 28, 189-193, doi:10.1016/1352-2310(94)900949, 1994.

Perri, M. J., Lim, Y. B., Seitzinger, S. P., and Turpin, B. J.: Organosulfates from glycolaldehyde in aqueous aerosols and clouds: Laboratory studies, Atmos. Environ., 44, 2658-2664, doi:10.1016/j.atmosenv.2010.03.031, 2010.

Rajapakse, M. Y., Fowler, P. E., Eiceman, G. A., and Stone, J. A.: Dissociation Enthalpies of Chloride Adducts of Nitrate and Ni- 
trite Explosives Determined by Ion Mobility Spectrometry, J. Phys. Chem. A, 120, 690-698, doi:10.1021/acs.jpca.5b10765, 2016.

Sareen, N., Schwier, A. N., Shapiro, E. L., Mitroo, D., and McNeill, V. F.: Secondary organic material formed by methylglyoxal in aqueous aerosol mimics, Atmos. Chem. Phys., 10, 997-1016, doi:10.5194/acp-10-997-2010, 2010.

Schwier, A. N., Sareen, N., Mitroo, D., Shapiro, E. L., and McNeill, V. F.: Glyoxal-Methylglyoxal Cross-Reactions in Secondary Organic Aerosol Formation, Environ. Sci. Technol., 44, 6174-6182, doi:10.1021/es101225q, 2010.

Seinfeld, J. H. and Pandis, S. N.: Atmospheric chemistry and physics: from air pollution to climate change, John Wiley, New York, 1326 pp., 1998.

Skog, K. M., Baltensperger, U., Collett Jr., J. L., Crippa, M., Decesari, S., Hodas, N., Kaltsonoudis, C., Laaksonen, A., Lim, Y. B., McNeill, V. F., Nemitz, E., Poluzzi, V., Prevot, A. S. H., Sullivan, A. P., Twigg, M. M., Turpin, B. J., and Keutsch, F. N.: Gas-phase Formic and Glyoxylic Acid Formation from Aqueous Aerosol Processing of Glyoxal during PEGASOS, Environ. Sci. Technol., submitted, 2016.

Smith, D. F., Kiss, A., Leach, F. E., Robinson, E. W., Paša-Tolić, L., and Heeren, R. M. A.: High mass accuracy and high mass resolving power FT-ICR secondary ion mass spectrometry for biological tissue imaging, Anal. Bioanal. Chem., 405, 6069-6076, doi:10.1007/s00216-013-7048-1, 2013.

Smith, J. N., Barsanti, K. C., Friedli, H. R., Ehn, M., Kulmala, M., Collins, D. R., Scheckman, J. H., Williams, B. J., and McMurry, P. H.: Observations of aminium salts in atmospheric nanoparticles and possible climatic implications, P. Natl. Acad. Sci. USA, 107, 6634-6639, doi:10.1073/pnas.0912127107, 2010.

Surratt, J. D., Kroll, J. H., Kleindienst, T. E., Edney, E. O., Claeys, M., Sorooshian, A., Ng, N. L., Offenberg, J. H., Lewandowski, M., Jaoui, M., Flagan, R. C., and Seinfeld, J. H.: Evidence for organosulfates in secondary organic aerosol, Environ. Sci. Technol., 41, 517-527, doi:10.1021/es062081q, 2007a.

Surratt, J. D., Lewandowski, M., Offenberg, J. H., Jaoui, M., Kleindienst, T. E., Edney, E. O., and Seinfeld, J. H.: Effect of acidity on secondary organic aerosol formation from isoprene, Environ. Sci. Technol., 41, 5363-5369, doi:10.1021/es0704176, $2007 \mathrm{~b}$.

Surratt, J. D., Gomez-Gonzalez, Y., Chan, A. W. H., Vermeylen, R., Shahgholi, M., Kleindienst, T. E., Edney, E. O., Offenberg, J. H., Lewandowski, M., Jaoui, M., Maenhaut, W., Claeys, M., Flagan, R. C., and Seinfeld, J. H.: Organosulfate formation in biogenic secondary organic aerosol, J. Phys. Chem. A, 112, 8345-8378, doi:10.1021/jp802310p, 2008.

Surratt, J. D., Chan, A. W. H., Eddingsaas, N. C., Chan, M. N., Loza, C. L., Kwan, A. J., Hersey, S. P., Flagan, R. C., Wennberg, P. O., and Seinfeld, J. H.: Reactive intermediates revealed in secondary organic aerosol formation from isoprene, P. Natl. Acad. Sci. USA, 107, 6640-6645, doi:10.1073/pnas.0911114107, 2010.

Tan, Y., Perri, M. J., Seitzinger, S. P., and Turpin, B. J.: Effects of Precursor Concentration and Acidic Sulfate in Aqueous Glyoxal-OH Radical Oxidation and Implications for Secondary Organic Aerosol, Environ. Sci. Technol., 43, 8105-8112, doi:10.1021/es901742f, 2009.
Tan, Y., Carlton, A. G., Seitzinger, S. P., and Turpin, B. J.: SOA from methylglyoxal in clouds and wet aerosols: Measurement and prediction of key products, Atmos. Environ., 44, 5218-5226, doi:10.1016/j.atmosenv.2010.08.045, 2010.

Tan, Y., Lim, Y. B., Altieri, K. E., Seitzinger, S. P., and Turpin, B. J.: Mechanisms leading to oligomers and SOA through aqueous photooxidation: insights from $\mathrm{OH}$ radical oxidation of acetic acid and methylglyoxal, Atmos. Chem. Phys., 12, 801-813, doi:10.5194/acp-12-801-2012, 2012.

Tolocka, M. P. and Turpin, B.: Contribution of Organosulfur Compounds to Organic Aerosol Mass, Environ. Sci. Technol., 46, 7978-7983, doi:10.1021/es300651v, 2012.

Volkamer, R., Ziemann, P. J., and Molina, M. J.: Secondary Organic Aerosol Formation from Acetylene $\left(\mathrm{C}_{2} \mathrm{H}_{2}\right)$ : seed effect on SOA yields due to organic photochemistry in the aerosol aqueous phase, Atmos. Chem. Phys., 9, 1907-1928, doi:10.5194/acp9-1907-2009, 2009.

Wexler, A. S. and Clegg, S. L.: Atmospheric aerosol models for systems including the ions $\mathrm{H}^{+}, \mathrm{NH}_{4}^{+}, \mathrm{Na}^{+}, \mathrm{SO}_{4}^{2-}, \mathrm{NO}_{3}^{-}, \mathrm{Cl}^{-}, \mathrm{Br}^{-}$, and $\mathrm{H}_{2} \mathrm{O}$, J. Geophys. Res. Atmos., 107, ACH 14-11-ACH 1414, doi:10.1029/2001JD000451, 2002.

Yu, G., Bayer, A. R., Galloway, M. M., Korshavn, K. J., Fry, C. G., and Keutsch, F. N.: Glyoxal in Aqueous Ammonium Sulfate Solutions: Products, Kinetics and Hydration Effects, Environ. Sci. Technol., 45, 6336-6342, doi:10.1021/es200989n, 2011.

Zhang, Q., Jimenez, J. L., Canagaratna, M. R., Allan, J. D., Coe, H., Ulbrich, I., Alfarra, M. R., Takami, A., Middlebrook, A M., Sun, Y. L., Dzepina, K., Dunlea, E., Docherty, K., DeCarlo, P. F., Salcedo, D., Onasch, T., Jayne, J. T., Miyoshi, T., Shimono, A., Hatakeyama, S., Takegawa, N., Kondo, Y., Schneider, J., Drewnick, F., Borrmann, S., Weimer, S., Demerjian, K., Williams, P., Bower, K., Bahreini, R., Cottrell, L., Griffin, R. J., Rautiainen, J., Sun, J. Y., Zhang, Y. M., and Worsnop, D. R.: Ubiquity and dominance of oxygenated species in organic aerosols in anthropogenically-influenced Northern Hemisphere midlatitudes, Geophys. Res. Lett., 34, doi:10.1029/2007GL029979, 2007.

Zhang, R., Suh, I., Zhao, J., Zhang, D., Fortner, E. C., Tie, X., Molina, L. T., and Molina, M. J.: Atmospheric New Particle Formation Enhanced by Organic Acids, Science, 304, 1487-1490, doi:10.1126/science.1095139, 2004.

Zhou, Y., Zhang, H., Parikh, H. M., Chen, E. H., Rattanavaraha, W., Rosen, E. P., Wang, W., and Kamens, R. M.: Secondary organic aerosol formation from xylenes and mixtures of toluene and xylenes in an atmospheric urban hydrocarbon mixture: Water and particle seed effects (II), Atmos. Environ., 45, 3882-3890, doi:10.1016/j.atmosenv.2010.12.048, 2011.

Zhu, J. and Cole, R. B.: Formation and decompositions of chloride adduct ions, $[\mathrm{M}+\mathrm{Cl}]^{-}$, in negative ion electrospray ionization mass spectrometry, J. Am. Soc. Mass. Spectrom., 11, 932-941, doi:10.1016/S1044-0305(00)00164-1, 2000. 